23 Westminster Terace

Glasgon.

west

*

H Y I I I I

IIN WHE

MER C A N T I I E Y A R I I B,"

BY

WI LIIAM WRIGHT, M.BGhB.\$:,D.P.H. (Cambr1dGo).

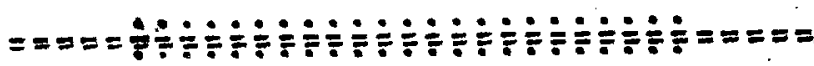


ProQuest Number: 27626727

All rights reserved

INFORMATION TO ALL USERS

The quality of this reproduction is dependent upon the quality of the copy submitted.

In the unlikely event that the author did not send a complete manuscript and there are missing pages, these will be noted. Also, if material had to be removed, a note will indicate the deletion.

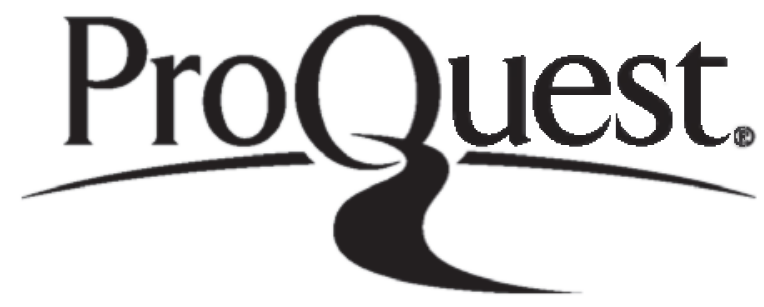

ProQuest 27626727

Published by ProQuest LLC (2019). Copyright of the Dissertation is held by the Author.

All rights reserved.

This work is protected against unauthorized copying under Title 17, United States Code Microform Edition (C) ProQuest LLC.

ProQuest LLC.

789 East Eisenhower Parkway

P.O. Box 1346

Ann Arbor, Ml 48106 - 1346 
Preface, . • • • . • • . .

Pages.

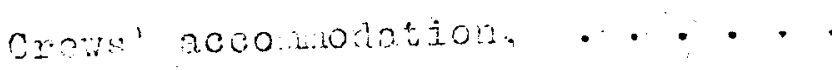

Sourity of Construction. . . .

Ligiting, . $\cdot \cdot \cdot \cdot \cdot \cdot \cdot \cdot \cdot \cdot \cdot$

Ventilation, . • . • • . . . .

Stokeholds, . . . . • . . • • •

Protection fron weather and sea. .

$1-2$

$2-3$

3-9

2

$3-14$

14-16

$1 \dot{6}$

Rffluvium caused by cargo and

bilge water,

$16-20$

$20-21$

Drainage,

$21-22$

cleansing

$22-23$

Cabins and Saloons, . . . .

23-24

Heating.

$24-25$

Temperature, • $\cdot \cdot \cdot \cdot \cdot \cdot \cdot \cdot \cdot$

$25-27$

Latrine Accomnodation, $\cdot \cdot \cdots \cdot$

$27-28$

Lavatory accominodation,

$28-29$

Cattle Ships. . • • • • • •

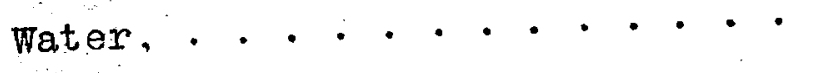

Food:

cooking,

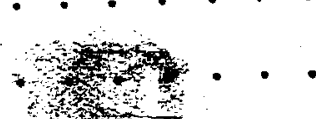

Preservation of Food.

$29-31$

$31-33$

$33-34$

34-35

$35-37$

Provisions

37

clothing.

$37-38$

Cargoes, . • • • • • • • •

Food Inspection, . $\cdot \cdot \cdot \cdot \cdot \cdot \cdot$

Diseases and Deaths, . . • • •

Conclusion.

$38-40$

$41-44$

44-45

ILLUSTRATIONS. -

$\begin{array}{cl}\text { Pages. } & 4 a(1 \& 2) \\ n & 4 b(3 \& 4) \\ " & 7 a(5) \\ " & 7 b(6 \& 7) \\ " & 10(8) \\ n & 15 a(10) \\ " \quad 18 a(11) \\ " \quad 19 a(12 \& 13) \\ " \quad 25 a(14 \& 15)\end{array}$


by

Wililam Wright, M.B CKB. .(Glas. Univ.), D.P.H.(Camb.)

The subject of which this work is comprised is the outcome of my expertence as Medical officer to the Glasgow Port Local Authority, and $1 \mathrm{~s}$ prompted solely by the opinion that santtary reform is urgently needed in the majority of vessels arriving in this port.

A ship, like a house, has its own Inhabitants, own water-supply, and own system of drainage. Added to this, It has a constant supply of fresh air. A sailor's life, therefore, should be a healthy one. In those lew words is expressed the opinion of the general public, and I desire now to show how erroneous such a view is, not only in respect of the health of its crew, but of emigrants and passengers. Were it possible that the crew could be accommodated on deck -- far removed from the effluvia arising from putrescible matter recognised on all vessels - - where eresh alr is constantly obtainable, there would then be no question but that a sailor's life would be one of the most healthful and invigorating. But, unfortunately, such highly desirable conditions do not presently exist in the Mercantile Marine, and, until much needed alterations have been effected, a sallor's life must be classifled in the list of unhealthy occupations.

A ship on the open sea has the solitary advantage of beine surrounded by air free from terrestrial emanations. In all other respects it is placed under unfavourable circumstances; for it combines the drawbacks of inadequate crew-space, of ventilation liable to frequent interruption, and of a moist 
atmosphere acting on vegetable matter, subject to decomposition.

It seems ludicrous to think that conditions such as overcrowing and extreme vitiation of atmosphere should exist in the midst of the boundless ocean -. yet such is the case.

A ship in harbour, though in other respects better circumstanced, is often exposed to the most deleterious emanations from low swampy lands and rich alluvial soils. A seafaring 11fe, moreover, is exposed to great and continuous fatigues, under cireumstances otherwise unfarourable to health, and, to a certain extent,.- often for lone periods of time -. to the erils of a monotonous existence. Hence the health of the seamen and passengers by sea can only be preserved by the most watchful care and attention to the cleanliness, dryness and ventilation of the ship; by the supply of fresh water; and by sound provisions embracing all the elements of a wholesome det, with suitable clothes and proper chanee of clothine, with fitting exercise, occupation and recreation, and with facilities for separating the sick from the healthy. The precise measures to be adopted to ensure those ends can only be fitly described by those who add to a general knowledee of the principles of hyglene, a special acquaintance with the construction and internal economy of ships.

\section{CREW'S ACCOMMODATION.}

The crew are usually accommodated in the forecastle, -1ther In a lower forecastle or a top-gallant forecastle, the firemen being placed at one side and the crew proper at the other, with a divisional bulkhead between. Occasionally, however,.- though very rarely -- the men are quartered amidships, the most desirable stuation in the ship; for here they have light, dryness, aeration, and general comfort.

The amount of space allowed by the Merchant Shipping Act of 1894 is 12 superficial feet and 78 cubic leet per man: in 
other words,

space measuring --

6 leet in length,

6 leet in height, and

2 feet in breadth,

a space which he is entitled to demand for his own grave. Picture, tien, a man sittine, eating, reading, writing (rrequently, even during the day, by the aid of a paraffin lamp), smoking - usually the heaviest of tobacco, spitting, wasing his clothes and person, and sleeping in his own grave. Were he actually in his own grave, the walls of his cubicle would be drier than those of the forecastle, which is only too frequently streaming with molsture, the result of condensation of the vaporous exhalations of its combined inhabitants. In this space, also, is erequently to be found different articles of ship's gear, tending still further to reduce the breathing room, as also to contribute other noxious odours. Yet a lamentable condition of affairs such as this is permitted to continue during an age characterised by the most rapid advances in Public Health Administration on shore. Had the spirit of the Act been strictly carried out, quarters such as lower forecastles for the crew would now be swept away, as they are most unsatisfactory and cannot possibly be kept in a sanitary condition.

Lower forecastles are below deck, and are entered by a hatch or opening in the deck, measuring usually $2 \frac{t}{2}$ feet square, sometimes covered with a scuttle, but often left open as the chief means of light and rentilation.

Under no circumstances should a steam windlass or other gear be permitted to remain in a forecastle. The heat and moisture at once render the place unhealthy, and there is, in addition, the danger from bursting of the steam pipes.

Gear stored in Forecastle:- Such articles may include all the different materials and implements on board which it is possible to stow away there; such as - sails, cordage, buckets, brushes, cans, wet clothes, paraffin, paint, 011, tar, and fre- 
quentiy provisions. All of them occupy space 1llegally, to the privation of the crew, and many of them pollute the air considerably.

There can be no justification for the continuance of lower forecastles, as the masters of vessels with deck-houses say that they cause no difficulty in the management of the ship. There is no doubt that in the deck-house is comprised the ideal accommodation, as it meets all the requirements in regard to plenty of sunlight, fresh alr, and healthiness generally. The minimum space provided by law is far too small, and, if strictly adhered to, men cannot possibly live in perfect health. To find the bare amount of space required by law is not very common, but still there is a falriy large percentage of such; The Royal Comission on Labour of 1894 recommended an increased air-space of $120 \mathrm{cublc}$ feet for each man. It is not on sea conditions that calculations should be based, but on those which obtain when the vessel is lyinf in port, when the crew are assembled together in places where they not only sleep but have to live. It is still not uncommon to find men occupying a forecsitle in which the deck above is much less than 6 feet from the floor, compelling them to remain in a bent posture whilst inside.

Deck-houses:- These have the sanitary advantages of light and air which lower forecastles do not possess, and which even top-gallant forecastles have imperfeetly. They are easy of access, and allow of more convenlence and comfort for the men. It is difficult to see why they are not more general in the Merchant Service; the testimony both of masters and crews $0 I^{\prime}$ vessels in their favour appears to be unanimous; nor do they interfere with navication. The space occupied by crews in forecastles woula be much more advantageously used for storage.

Figures 1 and 2 represent the plan and section of the crew arrangements on a German schooner of 150 tons. Dutch and German vessels are bullt according to the same plan. 


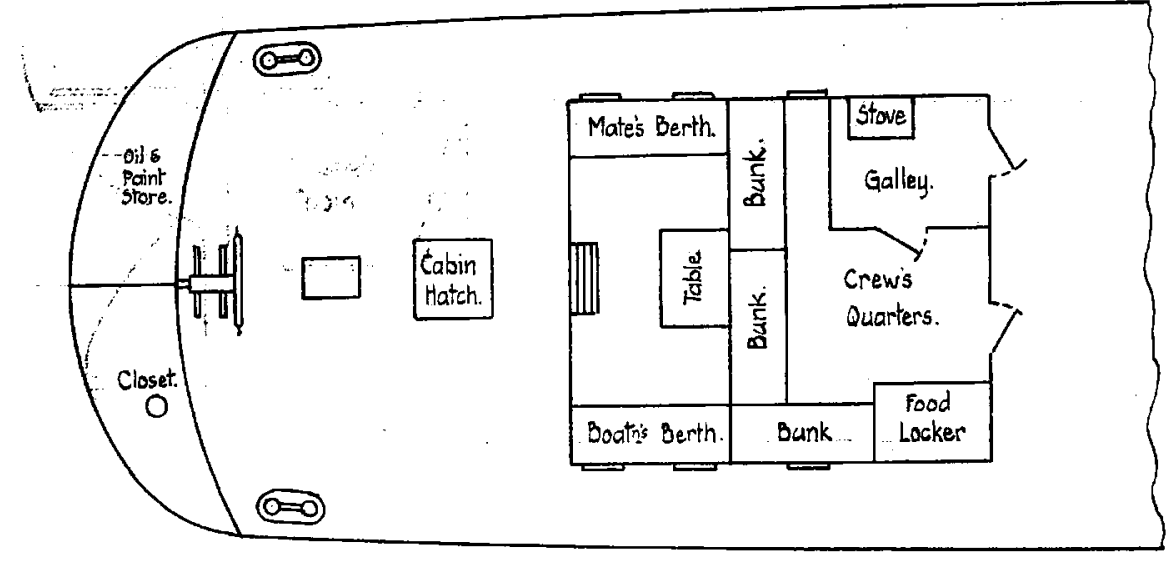

Fig. 1. Plan of Deckhouse on a German schooner (wood)

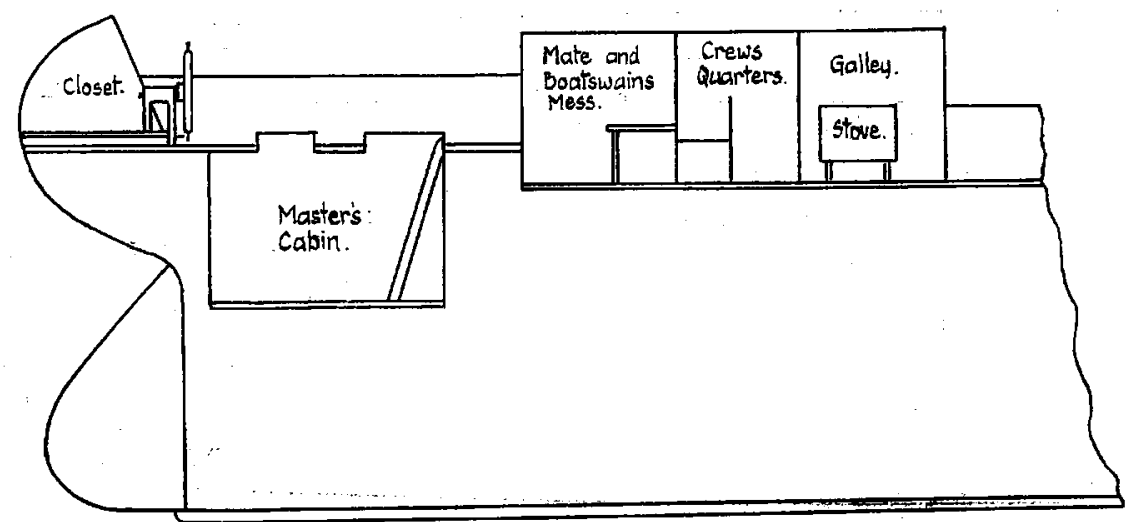

Fig. I. Segtion showing Arrangement of DeckHouse an A. GERMAN SEHOONER, (WOOD) 


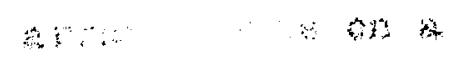

$\therefore \& 4$

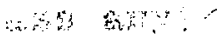

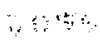

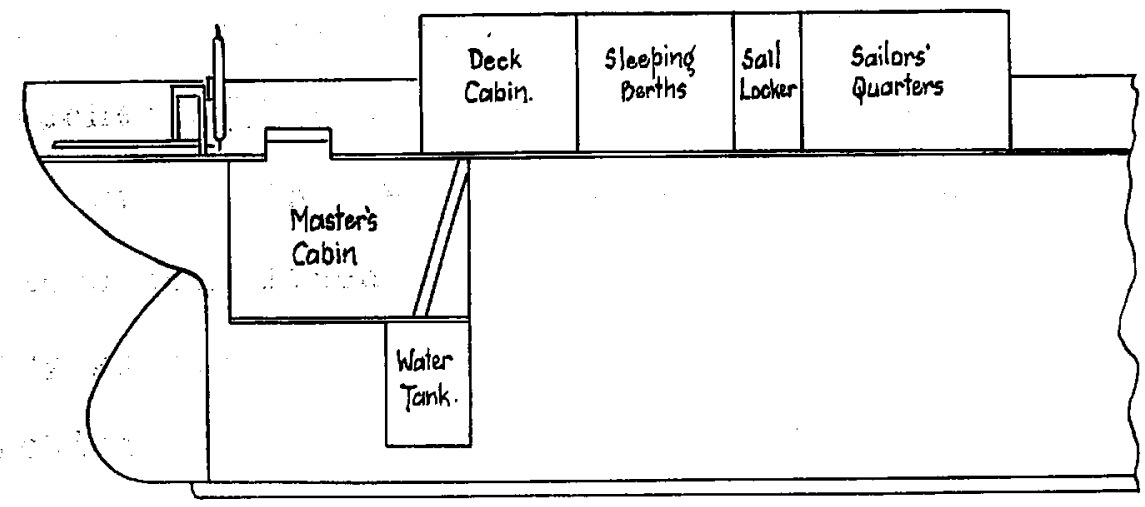

Fig.3. Section showing Arrangement of Deck.house ON A DUTCH VESBEL (IRON)

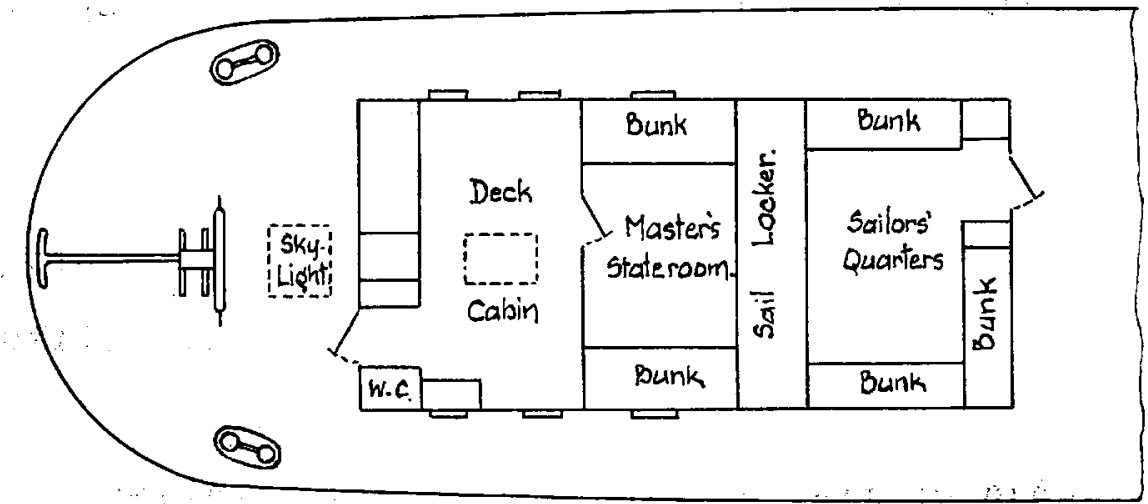

Fig.4. Plan of Deck.house on a duteh Vessel (Iron) 
Figures 3 and 4 are sections and plan of the crew arrangements on a Dutch sailing vessel, and typical of the many of this class. For comfort and cleanliness they surpass anything to be seen afloat.

The sides of the forecastle in iron ships contribute towards the production of moisture from condensation of the vapours exhaled by its inhabitants. Sometimes this $r$ eaches such a pitch as to keep the walls constantly streaming with moisture. To obviate this, many vessels have since been lined with wood, and, although it thus offers a dry surface, it only tends towards the accumulation of filth behind. Another method is to coat the sides with finely granulated cork; and of the two methods certainly the latter is to be commended, in that it can always be kept clean and regularly painted. All the vessels of His Majesty's Navy are now, I understand, lined with this material. It should be freely applied over all iron surfaces, both overhead and down the sides of the vessel, as there is no more frequent cause of complaint than the wetting of bedding from condensation Sweet Boards:--i.e., boards fixed immediately over the bunks,-- to some extent prevent condensation at that point, but it accumulates at the sides and is not thoroughly efficient.

Bunks should not be built close up to the side, but a sufficient interval should be left in order to permit a man to get round them to clean and paint them. Neither should bunks be made of wood, but of iron and painted a light colour; they should be of sufficient length and breadth, and in two tiers only, the bottom tier being at least twelve to eighteen inches from the floor. In some of the larger liners reaching this port it is not uncommon to see bunks placed in all available corners, absolutely dark, and little short of coffins. In the remainder of the forecastle the bunks are all in three tiers, the bottom of the lowest being 
only two to three inches from the floor -- thus preventing the possibility of removing filth, which readily accumulates there.

The position of food lockers also requires more consideration, as they are often built up against the partition of paint or lamp lockers, and sometimes against that of a closet. Paint and lamp lockers should never adjoin living rooms, unless separated therefrom by an iron bulkhead. Seldom does one ever see a thoroughly tight and efficient food locker, the majority being composed simply of roughly constructed boxes, usually without shelves or doors. The ideal position for food. lockers would be a specially constructed apartment outside the sleeping quarters, and well removed from possible contamination from water-closet, lamp or paint locker.

It is to be remembered that the internal fittings of forecastles do not usually form part of the main structure of a vessel, thus making it easier to obtain the desired reform. For the same reason, therefore, those matters receive little or no attention at the hands of the Board of Trade. They have merely to deal with an empty space where, fore and aft, bulkheacs, paint and lamp lockers, boatswain's and donkeymar's berths, and food lockers, as a ruls, are left to the discretion of the builders, who in this, as in other important sanitary matters, are allowed too much latitude. What is wanted is a properly recognised authority to supervise the constmuction of those places whilst the vessel is in the builders' hands. The officer of such an authority would not necessarily interfer: with the Board of Trade surveyor in the pursuance of his duties, but would serve as an adjunct thereto -- a recognised person, well acquainted with sanitary principles, to devote himself specially to that portion of the vessel pertaining to the health and comfort of its crew and passengers. 
Flgure 5 represents the usual accommodation on a well. decked vessel. The water-closets are on the same deck as the crew-space, being separated from it by store-rooms.

Figure 6 represents a well decked steamer in which: the men's quarters are placed amidships, with good arrangement for light and ventilation. The water-closets are placed WeII forward.

Figure 7 is the plan of a salling barque. Those are the best seamen's quarters that the writer has ever seen on any vessel. Their quarters are amidships. Each man has a separate berth to himself of iron, measuring six feet one and a half inches, by five feet one inch, by six feet two inches in height (more than double the space required by law). They are all lined with granulated cork throughout, and painted wite; and each has a port and a louvred ventilator in the door. Beneath each bunk is a chest of three drawers. In each berth, also, there is a washing basin and can, a seat and shelf. Abutting on the berths is a saloon with store, sideboard and skylights. They looked extremely comfortable and were sweet and clean. The captain said the men liked their accommodation, and remained for a long time with him.

It is to the interest of owners to give liberal accommodation to their crews, as, by enlarging the crew-space, they are reducing the dues (harbour, lights, etc.). They are charged on registered tonnage, which is determined by space other than crew-space, the latter being deducted. In factorles, the amount of space for each workman must not be less than 250 cubic leet; yet in forecastles, where men have to live, sleep and eat, only 72 cubic feet is allowed. The air-space should at least, therefore, be as ample as for a workshop. Under the "Passengers' Act" (Board of Trade notice to Passengers), all passenger ships are to be surveyed. The amount of deck-space required is, for each adult on the upper passenger deck, etc., not less than 15, and on the lower 


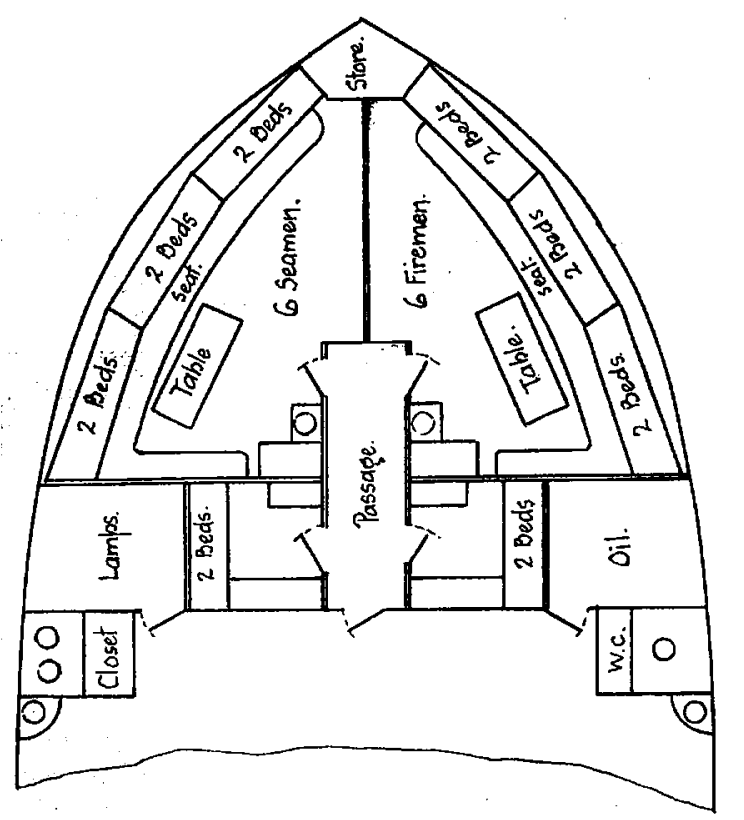

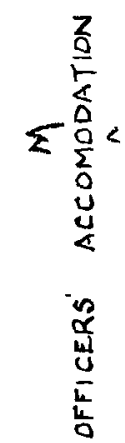

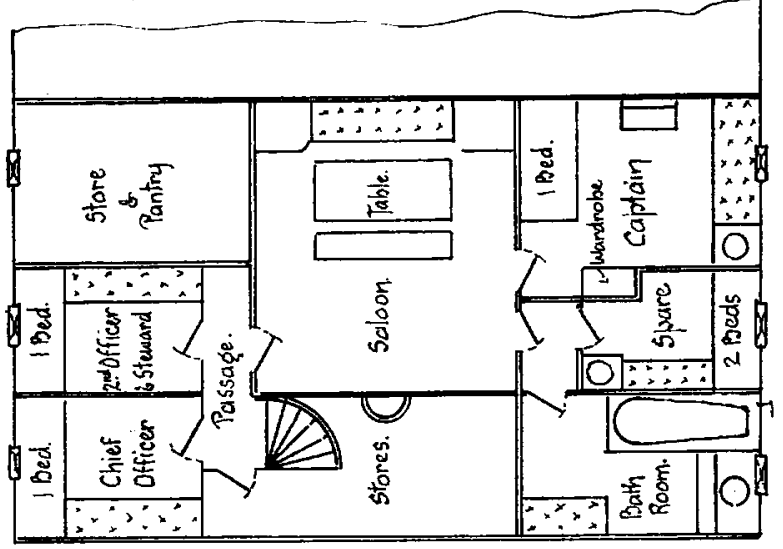

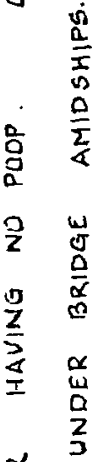

品

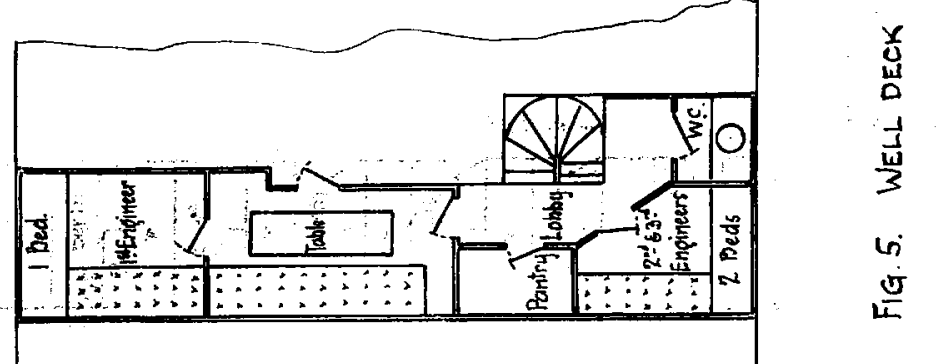



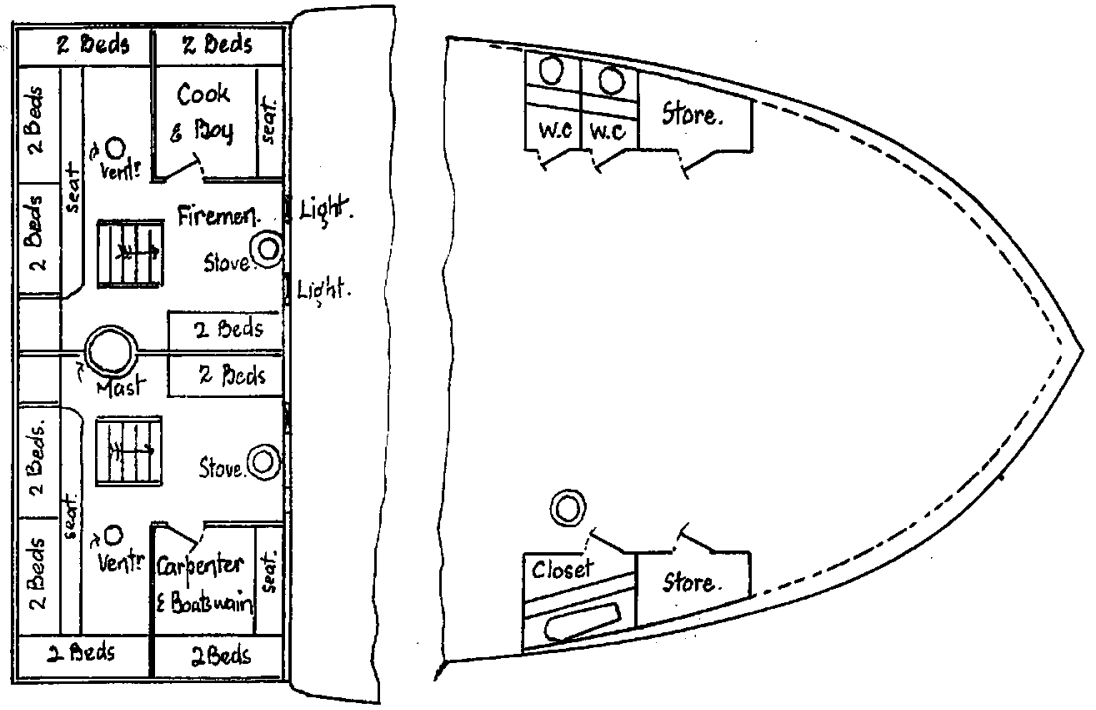

FIG.6. WELL-DECK BOAT WITH CREW UNDER FOREPART. OF BRIDGE.

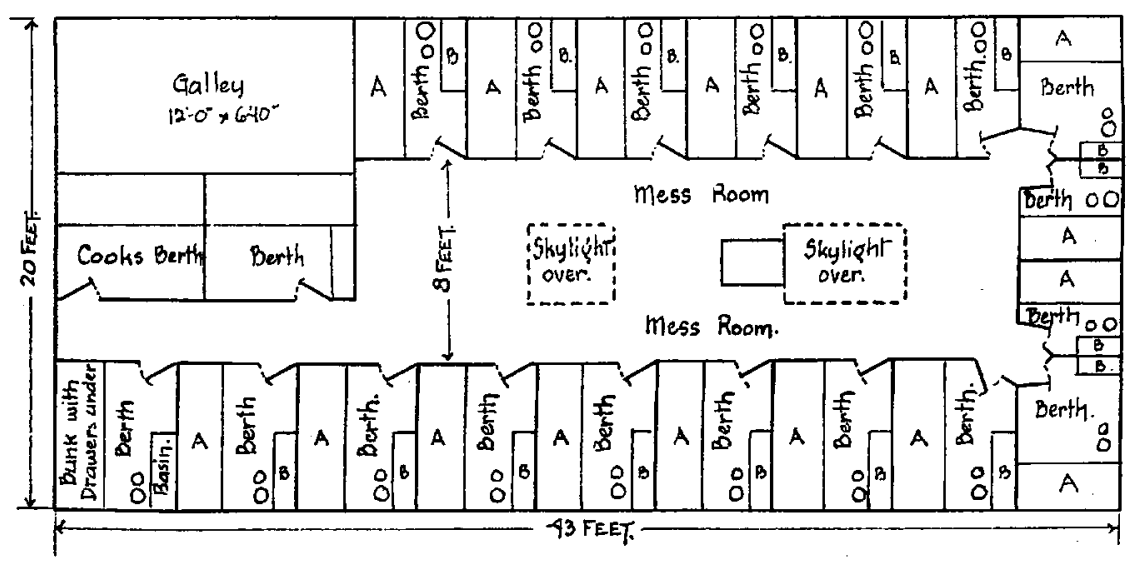

Fia.y. $A=$ Bunk with drawers undenneath. $B .=$ Basin. 
passenger deck 18 square feet. If the height between the latter deck and that above it be less than seven feet, or if the means of lighting and ventilation are below a specified standard, the minimum amount of floor-space per adult is 25 square feet. No ship is allowed to carry "a greater number of passengers on the whole than in the proportion of one statute adult to every five superficial feet, clear for exercise, on the upper deck or poop, etc. The height between any deck on wich passengers are carried and that above it should not be less than six feet, under a penalty not exceeding £50. There should not be more than two tiers of berths on any one deck, and the interval between each tier, and between the uppermost tier and the deck above it, shall not be less than two feet six inches. Hospital accommodation in the proportion of not less than 18 clear superficial feet for every fifty passengers must be provided. The lighting and ventilation must be such as the circumstances of the case may, in the judgment of the emigration officer at the port of clearance, require."

The sixth schedule of the Merchant Shipping Act of 1894 provides that all crew-spaces should be:--

Securely constructed;

Properly lighted;

Properly ventilated;

Properly protected from weather and sea; and, as far as practicable,

Properly shut off and protected from effiuvium which may be caused by cargo and bilge water.

\section{SECURITY OF CONSTRUCTION.}

Little comment need be made in regard to this point, as, for obvious reasons, it is usually complied with, only, however, in so far as the general strength of that portion of the ship is concerned but, apart from this, leakage is frequently complained of, through plates and inefficient ports on the ship's side, as also from the deck overhead, the planks 
having become spring as the result of the straining of the windlass overhead in raising and lowering the anchor.

\section{IIGHTING .}

On this point alone, without going any further, the Board of Trade subject themselves to condemnation. Few are the forecastles sufficiently lighted, and many of them are very dark. In almost all, the only provision to be found is that of side ports; the rays of light coming in therefrom, being in a lateral direction, are usually obstructed by bunks, etc., and therefore only serve to illuminate that portion of the quarters upon which the light airectly falls, leaving the remainder in comparative darkness. The floors are always in the dark, and dampness and dirt are thus encouraged.

\section{Deck-1ights:-- 1.e., glass prisms, let into the} deck overhead, -- are only available in upper forecastles, but those are, as a rule, conspicuous by their absence. Decklights could be more frequently supplied with benefit. Companion-ways, hatches, etc., cannot be depended on, either as a means of ventilation or lighting, as in bad weather they would be closed.

\section{VENTILATION.}

It is well recognised that ventilation on board ship is one of the most important points requiring consideration, and one which presents great difficulty in properly arrangirg. At best, the amount of breathing space in any forecastle is very limited, and, recognising that a healthy adult requires at least 3,000 cubic feet of air per hour, it behoves local authorities to give this matter their attention, in the interests of the merchant sailor.

The larger the vessel, the more complex does the question of ventilation become. The crews of war vessels are worse off than those of me rchant-men in regard to the purity of 
the air they breathe, owing to the larger number of hands and the difficulty of ventilating properly their quarters, all or most of which are, of necessity, below deck. The ventilation of ships might well be compared to that of an uncorked bottle. In two instances coming under the notice of the writer, the engineers' quarters opened airectly into the engine-room, arid the only means of ingress and egress was over an iron platform, above the engines, leading to the deck. It requires little stretch of the imagination to understand that those men, when the vessel was in hot regions, would be practically stewed.

Ventilators are too frequently absent, and, when present, are either stopped up with rags or are placed in positions apparently with Iittle idea, as to the purpose for which they are intended. Ventilators ordered by Port Local Authorities are placed in the most readily available spots, with regard only to the arrangements on the deck above. The majority of such forecastles have a hole about six inches in diameter through the roof, fitted with a cowl or mushroom ventilator, as in Figure 8.

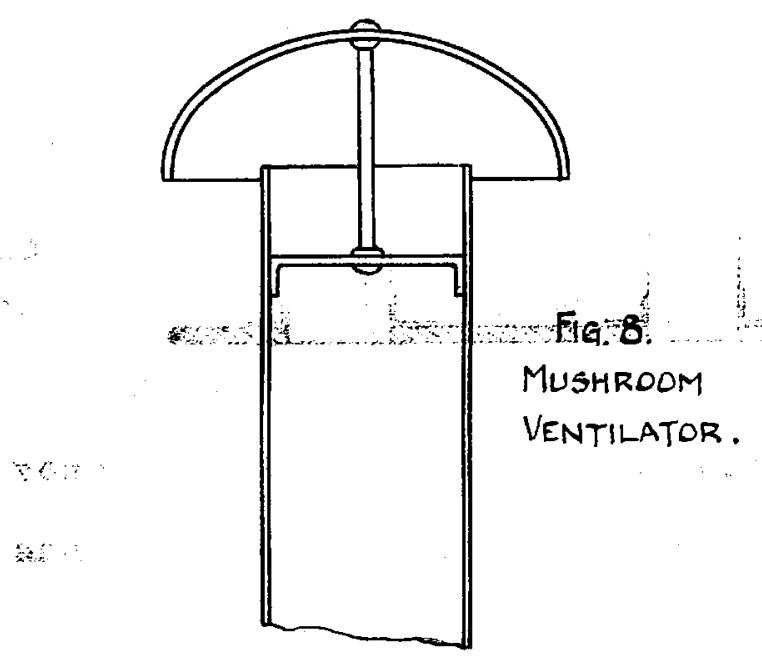

By placing two swan-necked ventilators just inside the knightsheads, where they will be well protected, and connected 
below the deck to each side of the forecastle by a pipe; and in the passage way, near to the doorway, on either side, a cowl ventilator: a constant through current would thus be Induced, and there would be no necessity to close them during rough weather.

Top-gallant forecastles have ports opening to the outer air, in addition to the other means of ventilation. The engine-rooms of steam vessels, and the cabins and saloons of passenger ships, are ventilated by hinged skylights. Holds are generally ventilated by cowl ventilators, the height of Which is regulated by the height of the structure in front of them, but in no case must they be less than six feet from deck to bottom of cowl. For vessels with one deck, the ventilation is as shown on E1gure $\mathbf{9}^{A}$.

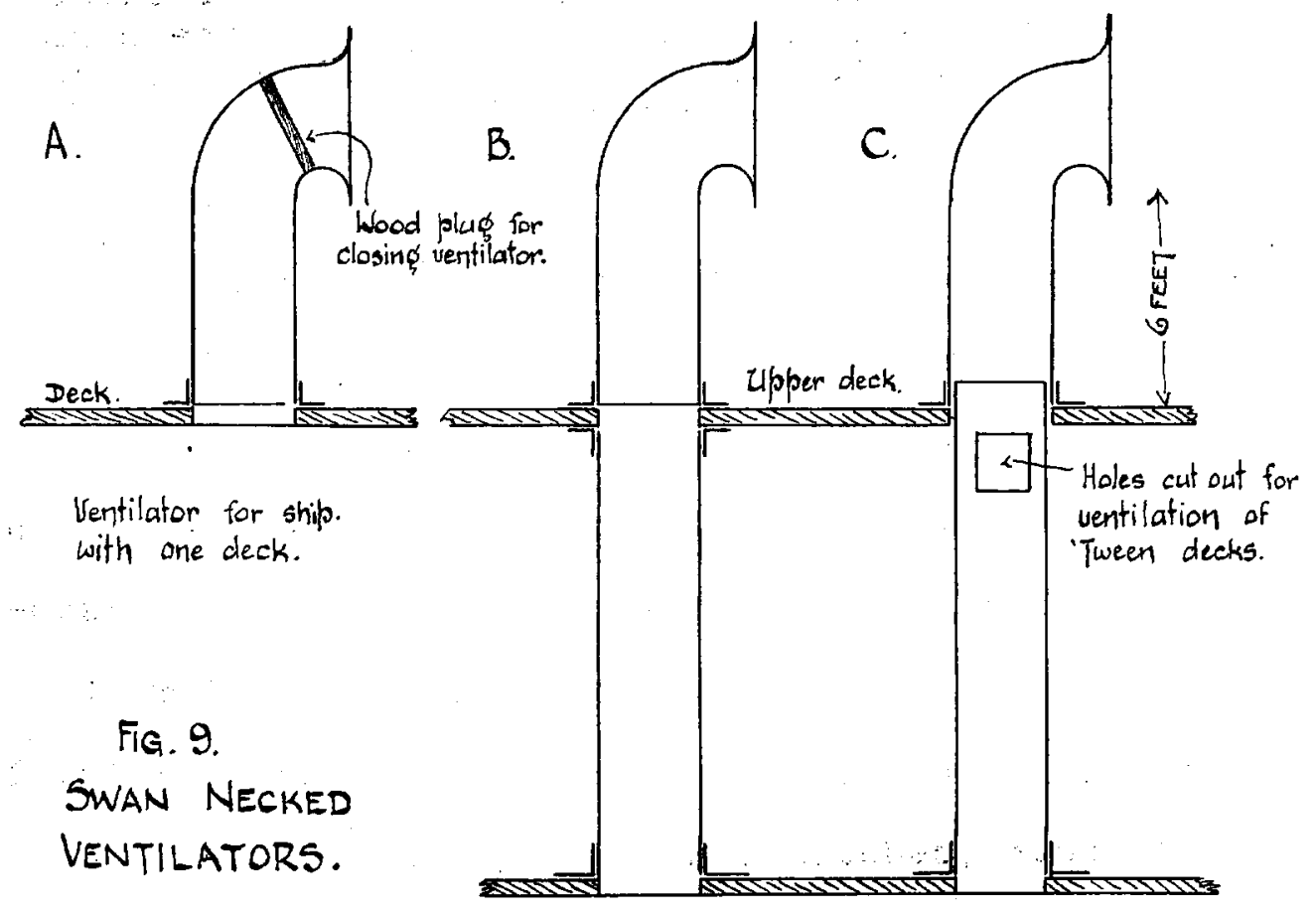

In vessels with two decks the form is given in Figure $9, \mathrm{~B}$. and $\mathrm{C}$ :

In tine "Instructions as to Survey," issued by the Board of Trade regarding the ventilation of a crew-space, the following is the text:--

"The simplest method is to have an iron pipe with a revolving cowl, which in lower forecastles must be as high as the bulwarks, fixed at each end or side of the crew-space, so that while impure air escapes at one, pure and fresh air 
will enter at the other, and a constant circulation be 1 cept up. Wren such means for ventilation is adopted, one of lue ventilators should pass through the deck to at least the lower side of the beams."

They discourage mushroom ventilators for forecasties. They are not fitted to these places unless they are at least 30 inches high for top-gallant forecastles, and as high as the bulwarks for lower forecastles. "There must always be two ventilators." It is needless to say that only too frequentily are those points aisreyarded, and many vessels has the writer personally visited where no ventilators were to be seen at all, and single ones are very common.

Under the "Passengers' Act" it is enacted that.-

"No passenger ship shall clear or proceed to sea without such provision for affording light and a ir to the passenger docks as the circumstances of the case, may, in the judgment of the emigration officer at the port of clearance, require; nor, if there are as many as 100 passengers on board, without having an adequate and proper ventilating apparatus as to be approved by such emigration officer and fitted to his satisfaction; the passengers shall, moreover, have the free and unimpeded use of such hatchway situated over the space appropriated to their use," etc.

The means of ventilation hitherto mentioned include those available through the ordinary openings of the different compartments of ships, and the simpler appliances in general use. Some of these are applicable only to the upper compartments; others are liable, from their height, to be swept off the deck in rough weather, and to leave openings for the inmash of water. As already mentioned, many of the so-called natural means of ventilation -- such as, hatches, companions, skylights, doorways, etc.,-- are of no service for this purpose, during a storm, having then to be closed. They are also generally closed at night, and at other times when the apartments to which they belong are occupied, and when their action as sanitary appliances is most wanted. It is therefore necessary to provide more elaborate apparatus, such as can be worked at all times, in all climates, independently of weather, on vessels for cargo or passengers, and on different parts of those vessels. Many forms of apparatus for artificial ventilation have been proposed:-- 


\section{Boyle's Ststem:--}

are aployed in combination.
Upcast and downcast ventilators

The foul air is exhausted by means of air pumps, which are fixec̃ and do not get out of order, and the fresh air is introduced by downcast pipes into the lower parts of the vessel. In this method, also, the fresh air is warmed or cooled to the desired temperature. The only obfection that can be offered to this plan of rentilation is that the shafts may be carried away by heavy seas, etc.

\section{Rotatory Fans:-- Various forms are in use for}

purposes of ship ventilation. Their special advantage is that they work without noise, and can be made to act either as inlets or outlets. The air can be similarly tempered before its supply to the saloons, etc. Crossley \& Blackman's air propellors are examples of these.

Those systems are an improvement on the crude methods of introducing currents of cold fresh air from the outside, allowing the foul air to find its way out as best it could. The inlet air must enter freely, else the action of aspiration will be feeble. In large saloons the passage of air from inlet to outlet necessitates considerable force. To procuce

a steady and gradual removal of the products of respiration, and the interchange for them of fresh respirable air from the outside, extractive and propulsive power in combination would seem to be necesary. The latter mist be so provided that, though ample, it is under ready control, and the air it sets in motion must be diffused gently and evenly without creating perceptible draught. On board ship they should necessitate no long shafts, which might be carried away by wind and sea. None of the above methods appear quite to meet the requirements. Other Methods:- have been suggested, such as that by means of compressed air ( 3 1bs. to the square inch). They clain that every cubic foot of compressed air will induce a current of 25 cubic feet of air, tempered or not, as desired. Some other ingenious inventions have taken advantage of the 
movements of the ship at sea for the purpose of ventilation, one acting by rolling and the other by pitching. It is obvious, however, that any system of ventilation based on the roll of pitch of a ship must fail in its operation when the vessel is at anchor, becalmed, or moving steadily.

\section{STOKEHOIDS.}

Those, from a sanitary point of view, are important parts of ships, as it is from here the furnaces are coaled, situated as they are at the bottom of the ship, deeply below the water. In the smaller class of vessels there is only one stokehold to each steamer, but larger ships have two or more. They are generally provided with wide cowled shafts for the delivery of cold fresh air from the upper deck, the hot and consequently light air being allowed to escape upwards. For econorry of space, the stokehold is usually made no wiaer than is ansolutely necessary -- say, 8 feet, -- the width and depth being those of the ship. The stokers, therefore, work in a deep well, and are exposed to great heat from the furnaces, from which they are unable to withdraw whilst on duty. The air at the bottom of the stokeholds tends to become very foul, by reason of the escape of various gases of combustion from tine fires. These gases, from their greater density, are not carried upwarde with the warmed air, and the supply of fresh air by the cowled shafts, before-mentioned, does not counteract their evil effects. The effect of the stokehold on the stoker is detrimental to a high degree, and firemen are, in consequence, proverbially unhealtry. There is little difficulty in distinguishing a fireman from a seaman, as his emaciated look bears the tmpress of his calling. It is not uncommon for men to work at firing in a temperature of $130^{\circ} \mathrm{F}$. , and $110^{\circ} \mathrm{F}$. is quite common. There has been very little heed paid to this matter hitherto; the ship designer does not seem to think of it; enough for him if his speed is attained at the trial trip. The result of this incessant heat is the 
number of firemen who commit suicide, whtch is out of all proportion as compared with other classes of men. It is unfortunate that the Board of Trade, in working up their annual statiatics, dont inquire more rigorously into the causes of such a high mortality of this kind amongst firemen of the mercantile marine. The heat of the stokehold is not so great as that of the side Bunkers, as the boijer-room is not insulated from them by non-conductors, and a temperature of $160^{\circ} \mathrm{F}$. and upwards $i$ often found there, viz., almost twice tre temperature of the body in health. Considering, therefore, the trying conditions under which the duties of marine engineers and firemen are carrled on, it might be expected that everything possible woulc be done to minimise the unhealthiness, discomfort, and dificuztjes of their work. But, unfortunately, that consideration does not obtain to the extent it might. Tunnels are ofter Without ventilation. Fingine-rooms and stokeholds have it, but only partial and illmirected. Furnaces are either extremely high or extravagantly low, all adding unnecessarily to the labour and exhaustion of both classes and to the cost of working the ship. When the direction of the wind in at richt angles, or in a line with the ship, (that is, abeam or abaft) ventilators of the cowl variety are next to useless; congequently the little air that can be obtained is by induced cur. rents, and is all that can be relied upon. Under these circumstances, for men to remain stoking four hours without Eoing on deck may be possible in high latitudes, but it is practically Impossible to do so in hot climates, when the temperature is between $110^{\circ}$ and $140^{\circ} \mathrm{F}$. It is a common occurrence for the men to go on deck after every "fire up" for fresh air, in a halfexhausted state and in clothes drippine with perspiration, to encounter a difference of temperature of from $30^{\circ}$ to $60^{\circ} \mathrm{I}$. When the wind is blowing in a direction opposed to that of the ship (that is, ahead or before the beam), firemen are able to remain below, oy standing immediately beneath the venti- 
$50 \therefore \quad \therefore \quad 460$

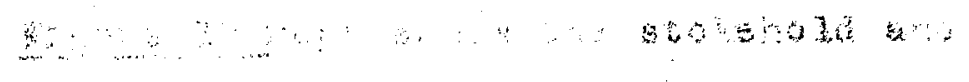

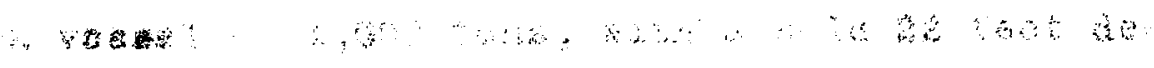
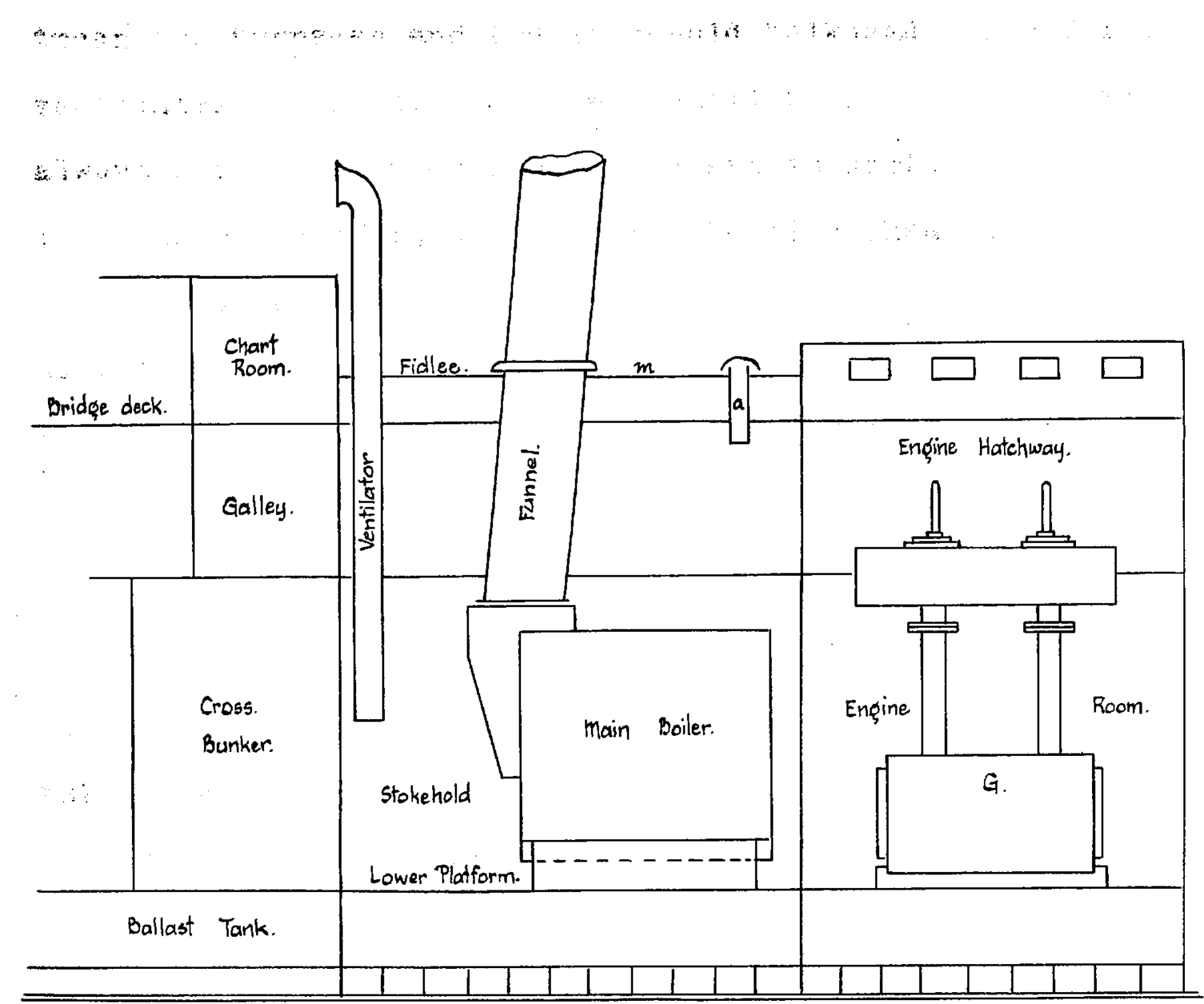

FIG. 1D. SECTION SHDWING STOKEHOLD ETC.

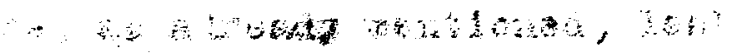

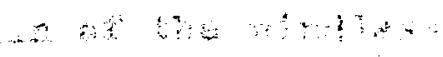

tos

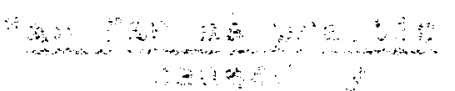

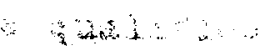




\section{- $16 \quad--$}

1ator. This they do after stokine the fires, tinus exposing themselves, in their enervated condition, to a greater difference of temperature than by going on deck, a proceeding which cannot but be deleterious to healti.

Figure 10 represents the stokehold and engine-room of a ressel of 1,000 tons, with a hold 22 feet deep, the space between the fournaces and the stokehold bulkhead being $7 \mathrm{ft}$. 3 Inches, ventilated by two 27 -inch cowl ventilators. Whether these will always prove effective and sufficient in admltting fresh ais into the stokeholds, except with the wind ahead or before the beam, is a question which may be answered in the negative, and no proper diffusion of air throughout the stokehold can be expected. This inethod of ventilation, therefore, cannot be relied upon for the followine reasons:--

(1) There is too little space on the platform.

(2) The ventilators are too near the funnel and boiler.

(3) The egress for the hot air is inadequate.

There should be at least 10 seet space between the furnaces and bulkheads or bunkers, and sufficient space above the uptake of bollers, so that the scape of hot air should be facilitated in every possible way.

\section{PROTECTION FROM WEATHER AND SEA.}

Lower forecastles may be considered sufficiently protected from weather and sea, but not so in the case of upper forecastles, where, as alreadj mentioned, leakage is common, due to the strain of the windlass, bits, etc.

\section{EFFIUVIUM CAUSFD BY CARGO AND BILGE WATER.}

The Act raads -- "as far as practicable shut off and protected from effluvium, which may be ${ }_{\wedge} c a r g 0$ and bilge water." The qualification is aving one, and this provision, therefore, from a hyglentc point, is a dead letter, for practically no vessel is without effluvium from cargo or bilges. The reason is only 
too evident, and is to be found in inefficiently caulked lintres and floors, and defective bulkheads; and is the result of the constant straining of the ship. All possible crevices or inlets to sleeping quarters should therefore be carefully examined, and re-coulked or remedied immediately when found.

Before proceedine to describe the effect of the offluvia from those quarters, it will be necessary in a few words to enter into a description of the construction of a vessel, in order to thoroughly comprehend the situation of those parts and their relation to the health of its crew and passengers. The skeleton of a wooden ship consists principally of the following parts:--

(1) The keel, running the entire length of the bottom of the ship, terminating in (2), the sten or foremost part of the ship, with which it forms an angle of about 90 degrees; and behind in (3), the sternpost or aftermost part of the ship proper. To the keel, at regular intervals tinroughout its enitre length, and curving outwards not unlike the ribs of the human spine, are (4), the timbers. Those in the bow or front parti of the ship are termed cant timbers; those aft of the cant timbers are the erames. The sternpost supports (5), the stern, which curves underneath as the counter. The planking (6) is fixed external to the frames, and $r$ uns horizontally the entire length of the ship; the main-rall (7) fixes in position tine upper ends of the frames. The curved part of the outside and bottom of the ship below the water-line is the bilge ( 8 ). The highest part of the side above the level of the upper deck is the bulwark $(9)$. The framing is lined inside with planks. This and the planking on the outside of the frames are called the "sking" (10), the whole formine the wall of the ship. Between the skins in the intervals of the frames is a space in the wall, closed in at the top by the covering board (11), and extending downward to the bottom of the ressel, where it ends in the limber 
or bllge, a longitudinal channel parallel to, and one on each side of, the keelson (12) - - a kind of inner or upper keel.

Figure 11 represents diagrammatically a midship section of a wooden three-decked vessel. The parts of hygienic interest in connection with it are -- (1) the Decks, each resting on beans extending transversely from one side to the other, and supported on shelf-pieces or projections from the inner skin; those beans are planked on the upper surface, which is slightly curved, especially on the upper deck, so as to throw off water to the side, where it comes in contact with the waterway, a projection from the inner plankine above deck, corresponding, in position, etc., to the shelf-beam below deck; (2) the Hold, situated below the lower deck; (3) the fimbers or biless, shown on Section, one on each side of the main keelson, with covering or limber-wood, and forming by means of water-courses through the floor timbers a continuous longltudinal channel; and (4) the Ventilating Channel in the inner skin below each deck, which may, as shown in the diagram, serve either as an outlet from the tween decks or an inlet for foul air from the bilge.

From the foregoing description it will be seen that water falling on the upper deck will flow to the waterways, where it is discharged overboard by means of the scuppers or outlets through the bulwarks. Drainage andliquids from cargoes falling on the lower decks and floor of the hold pass into the bilge. Leakage from the sea through the seams of the outer planking finds its way between the skins into the bilge, and thence to the well or sink where the pumps are placed to dis:charge it overboard. In steamships the water on the floor of the engine-room, and drippings of oil from machinery, etc., flow to the bilges.

Iron ships have keel, stem, sternpost, frames, beams, etc., as in wooden ships, but all are made of metal; the planks of the latter are in the former replaced by Iron plates; and the decks and transverse partitions (bulkheads) dividing the vessel 


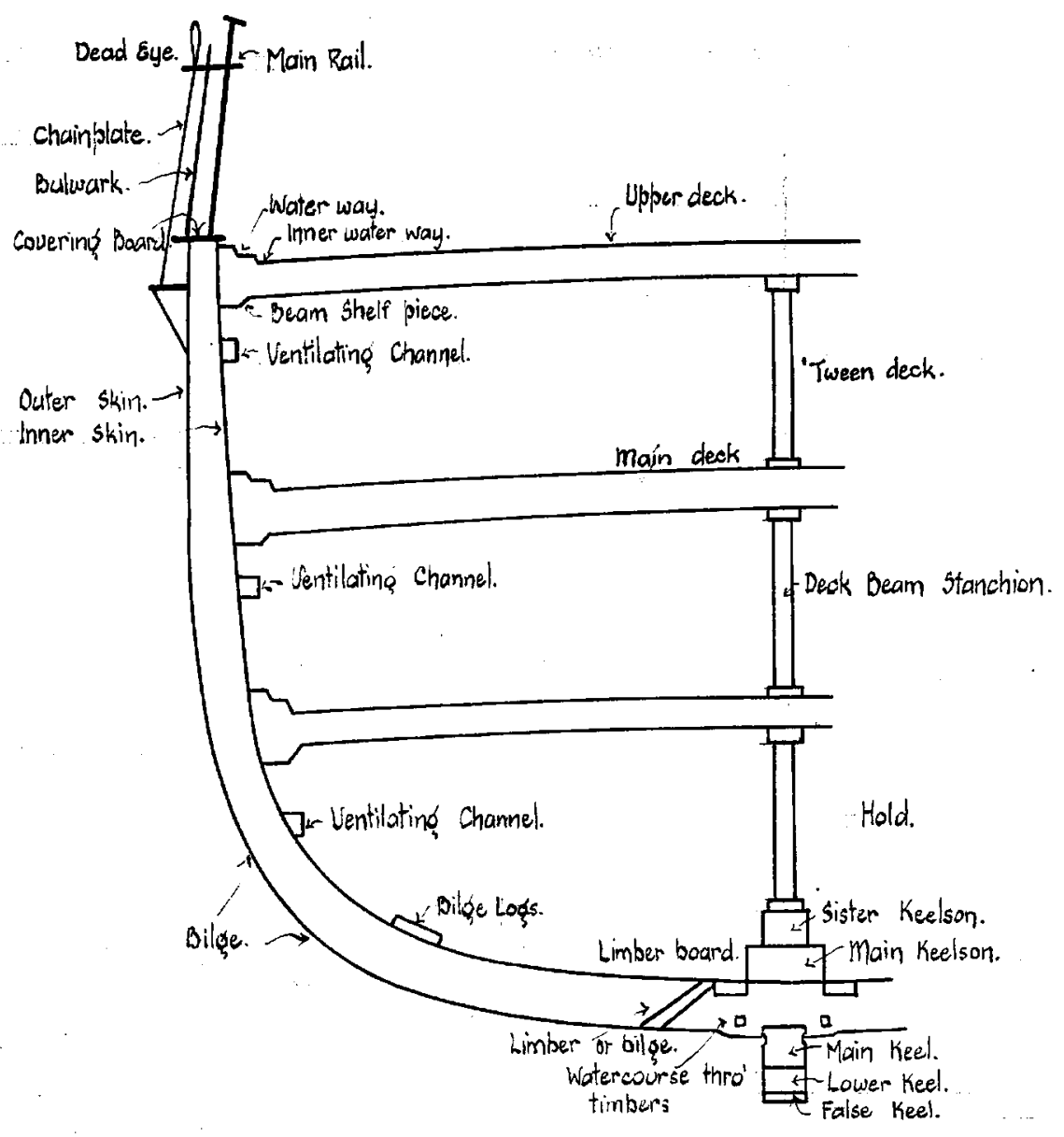

FiG HI MIOSHIP SECTION DF WOODEN SHIP. 
into comportments also consist of iron plates.

Bilge Water is the essence of nastiness, and $1 \mathrm{t} s$ effluvia one of the most serious nuisances on board. The bilge is the sink of the ship, and the exhalations from it are much more offensive than the "ground air" of a house.

It is, in fact, more like sewer air. The perpetual motion of the ship, although available for purposes of ventilation, only tend to Increase the evolution of gases from below, by the constant afitation of the bilee water. The sea-water in the bilges con. centrates, and, under the action of orfanic matters of varicus kinds mixed with it, becomes decomposed, giving off sulphide of ammonia, sulphuretted hydrogen, and other gaseous vapours and compounds, which are diffused through the ship. One of the most abominable of all the many stenches of bilge water is tiat resulting from the arippings of a sugar cargo into the bilfes, $\mathrm{s}$ sugar carto is liable to heat and give off offensive effluvia. Few occupations are more noxious and revolting than that or cleaning out the b1 kes of a vessel which has been employed in carrying a suear caręo. I have personally witnessed the procedure on several occasions at Greenock, and any description of mine would fall far short of conveying anything like a conrect impression of the nature of that duty.

Another ceuse of foulness of the air of ships is the cargo 1tseif, which may consist of guano, manure, fish, csttle, etc.; gas tar, paraffin, etc., from leaking casks in carcoes also make their presence felt. In cattle ships the accumulatior of dung, etc., pollutes the air of ships greatly,

Flgure 12. shows what is common to most lower forecastles. The hiaden bilee (a) (a) (a) is probably the worst reature to deal with, as it cannot possibly be thoroughly cleansed. The older the vessel, the more liable will this be to pollution from impurities due to dec ay and other causes. (b) is the coalbunker below the forecastle floor, access to which is usually by 


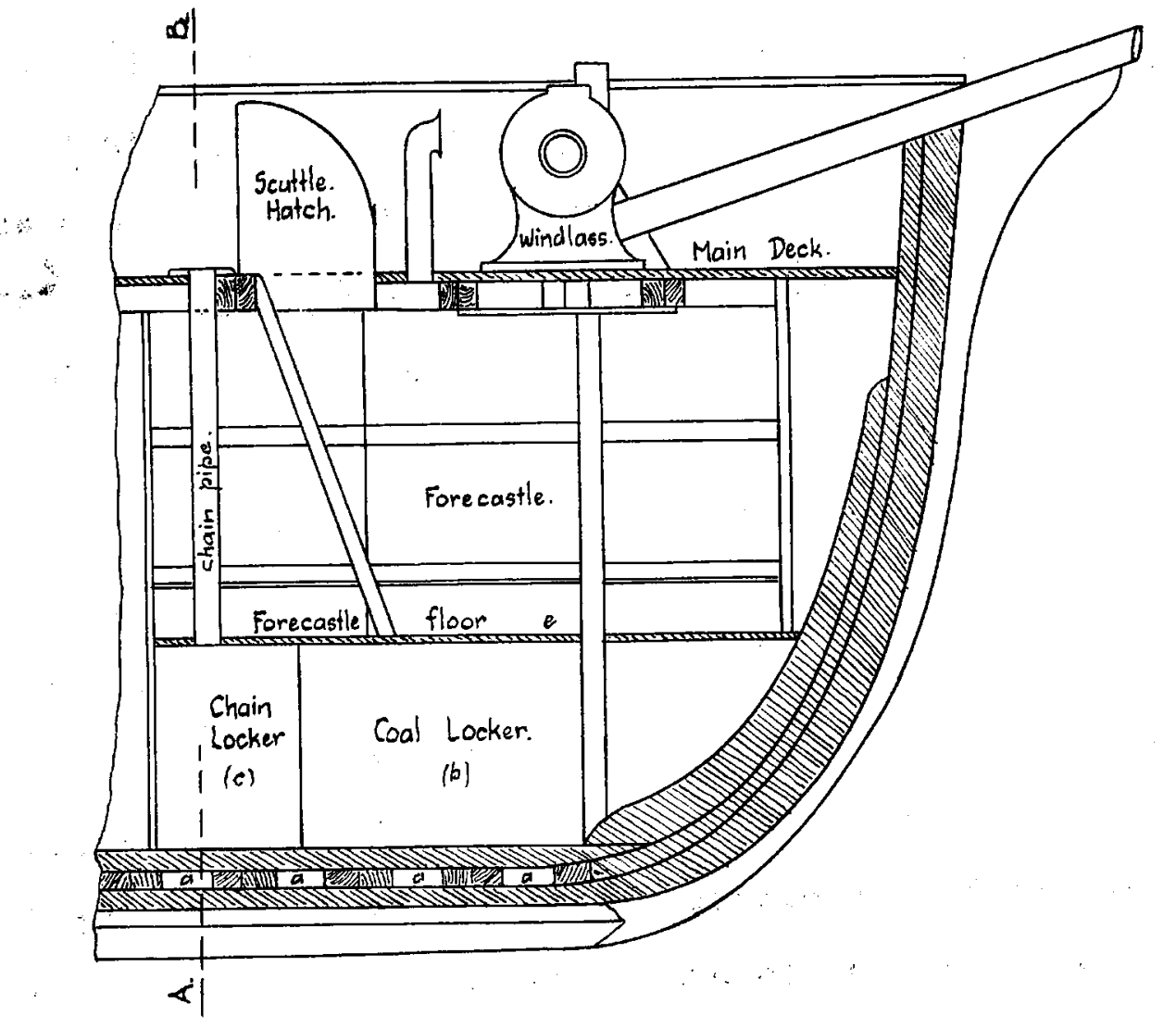

fig. 12. Section thro lower forecastle.

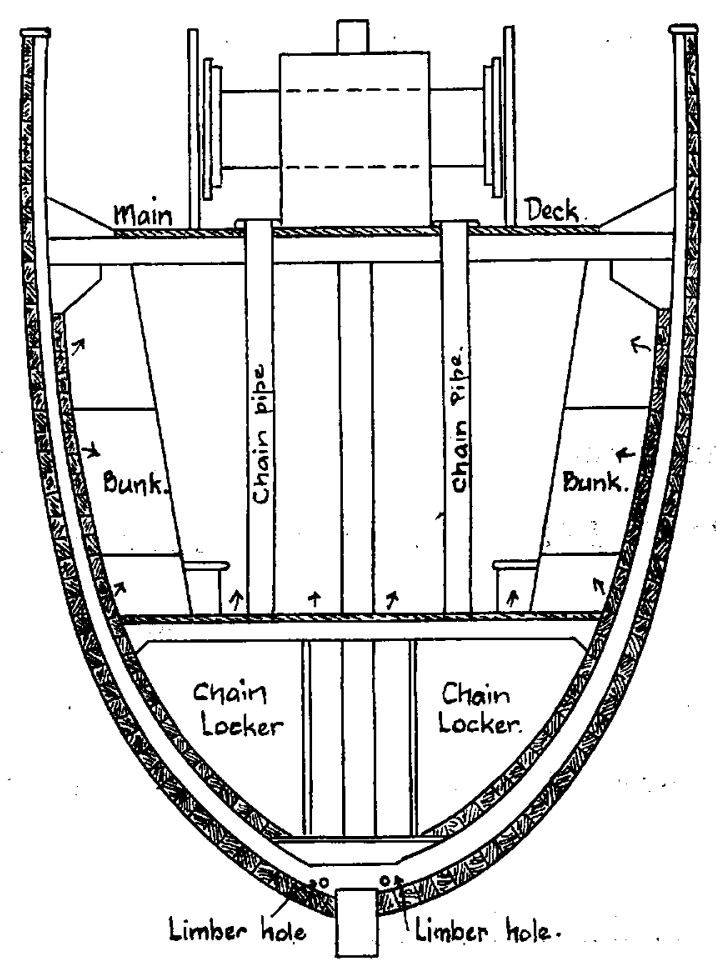

Fig 13. Transuerse section at A.B...: (LOOKING Forward) 
an 1ll-fitting hatch. The floor (e), from constant traffic, is never properly tight, and any water spilt or used in cleansine purposes finds its way into the coal and chain lockers (c). The foul air arising from the bilees finds its way between the frames and through the uncaulked and defective Iinine (marked by arrows in $1 i_{1} .13$ ), which have been eaulked when the vessel was new, but is sela om renewed afterwards.

Taking into consideration the fact that bunks where men have to sleep, and food-lockers where the dally and weexly provisions are stored, are bujit up apainst this lining, 1t can well be imagined that the existence of human beines in these stuffy and malodorous places is not to be envied. Similarly the Pore-peak is a source of nuisance; the entrance to it is through a trap in the floor of the crew's quarters. This hatch is likewise seldom t1ehtly secured, and hence offensive odours finc their way readily into the crev's sleeping quarters. The situation of the fore-peak is thus a bad one, as everything has to be carrled through the quarters. The fore-peak should never open directly into the forecastle, but ought to be separated therefrom by a passage leading direct to the hatch.

The Chain-locker is another source of nuisance, situated, as it is, below the forecastle floor. There is always a certain amount of mad adherine to the cahle, and consequently we have a damp mass giving off a most unpleasant smell, imediately beloN where the men sleep. This is still further increased when the pipes which enclose those chains are defective, when a direct communication is thus established between the two places. All chain pipes should be regularly examined.

\section{DRAINAGE.}

All decks' surfaces are curred to cause the flow of water towards the sider, where it is drained into the scuppers and dischareed through the bulwarks. Lower decks are similarly 
curved upwards in the $\mathrm{mldd}$ le, being drained by scuppers leadine to the bilees. Leakage through the sean of the outer skin of the ship also finds its way to the bilges. All this water, therefore, chareed with whatever it has come in contact in its passage through the ship reaching the bilges, is drained to the limbers, and thence to the well or sink, where it is pumped overboard from time to time. If the bilges be flat, the water becomes stagnant; the suspended matter it contained sinks to the bottom, causing filth and evolution of foul gases. This defect produces, as already described, a great danger to the health of the ship's crew and passengers. The pumps sholic be used at regular intervals, and should be capable of clearing out all of the bilge water.

$$
\text { Limber chains -- i.e.e, chains disposed so as to work }
$$

in the length of the limbers by stirring up dirt lodged there.. prevent deposit. All bilee floors should be cemented over and made perfectly smooth, with a fall on both sides to the well. The b1lges should be regularly pumped dry, and flushed with disinfectant solution, a sufficient quantity of disinfectant beinf left in order to cover the floors well on each side of the well.

\section{CIEANSING.}

In well conducted ships a periodic inspection is made by the officers of the ship of the quarters occupied by the crew, in order to ensure their beine kept clean. This rule, al though carried out on board most of the larger vessels, is seldom, if ever, given effect to on smaller vessels. The commonest fault Is to use water too frequently and in unnecessarily large quantities. Thorough scrubbing and cleansing can be effectively carrled out without the use of large quantities of water, which very often (charged, as it is, with organic matter) by accumulation in out of the way corners, is productive of more trouble than the original dirt. Great care shoulc be taken to see that 
all superfluous water is got $r i d$ of, and that the forecastle is dried as quickly as possible; in wet or damp weather dry scrubbing should always be resorted to.

"A damp ship is an unhealthy ship." This may be accepted as an axtom, the truth of which has been constantly demonstrated. Air is ary or moist, not in proportion to the actual amount of water it contains, but according as it is more or less removed from saturation. This degree of saturation is termed "relative humidty"! The normal amount of molsture exhaled by an adult is more than sufficient to render the cubic space provided saturated, without any additional means; apart from the pernicious effects of molsture per se, it has $a$ powerfulinfluence upon the development and growth of germs of disease It is to be remembered that there can be no more fatal source of disease amongst seamen than the constant inhalation of a damp atmosphere, whether sleepine or waking, but particularly is this influence infurious when the moisture exists between a ship's decks, where it may be at the same time more or less impure and hot or cold, accoraing to circumstances. Bearing the se facts in inind, the greatest care shoula be at all times taken to keep the crews' quarters as dry as possible. It shoula also be a rule that, whenever the weather will permit, all beddine should be removed from the forecastle and exposed to the action of the wind and air for a certain time every day.

\section{CABINS AND SATHOONS.}

Between the men and any officer, however low his grade, there should be a distinct and decided difference made and maintalned, especially with regard to his housing. It is, unfortunately, often the case on large and well-found steamvessels that the junior offlcers are even worse off than the men with reference to space. A cabin constructed to accomodete two seamen is utilised for two officers. This is a point which requires attention. Again, officers' cabins are frequently badly ventilated. Situated at the side of an alley-way, close to 
the engine-room and stokehold, from which there is always a current of hot air, they really require more thorough ventilation than the forecastles, while, as a rule, they obtain less. Good large scuttles should be provided, as well as some simple arrangement for ventilation in the door and over the bulkneads. In addition, when possible,-- and this is nearly always the case -- ventilating tubes should be carried through the deck, terminating, according to circumstances, either in cowls or swan-necks. As in the forecastles, the decks should be permanently laid and water-tight; and the side and deck, if of iron, carefully insulated with granulated cork. It is ever common for passengers and captain to have closet and bathroom placed together. This is a most objectionable arrangement, and, except where both are used by the one person only, it is difficult to conceive any advantage. The aischarge pipes should always be separate and distinct, to aroid the possibility of the bath being fouled by the washing back of the soil from the cabinet. For the same reason, also, water-closets should not adjoin, nor be immediately above passengers rooms, as when these go wrong evil odours result, the fluid sometimes finding its way therein.

HEATING .

In almost all the larger liners, a proper stearipipe arrangement is supplied. This, probably, is the best, safest, and cleanest method of furnishing the necessary amount of heat consistent with the requirements of health. It is only In regard to their situation that complaint can be offered. Frequently the radiator is placed either in the passage-way between the two forecastles, in a corner, below a bunk or at elther door, and thus a proper diffusion of heat throughout the whole forecastle is not afforded. If placed in the centre of their quarters, of fair size and properly insulated, more benefit would thereby be obtained. 
The old-fashioned bogie, which still exists on bourd the smeller vessels, is of little use. This takes the form of a small square stove, constructed of thin cast-iron, and is either red hot, choked with ashes, or broken beyond repair. A circular wrought-iron slow combustion stove, lined with fireclay, would be more serviceable, less costly, and supply a steady heat when charged.

TEMPERATURE.

The temperature of a ship depends on three factors:--

(1) Whether or not she is constructed of metal.

(2) Whether or not she is propelled by steam.

(3) The nature of her cargo.

(1) In tropical climates, all the Iron portions of the ship, decks, divisional bulkheads, state-rooms, officers' and seamen's quarters, etc., become exceedingly hot, and this heat, by conduction, etc., is imparted to all parts of the ship. This could be obviated, to a great extent, by painting the sides of the ship white, which less readily absorbs the sun's rays. Conversely, iron ships in high latitudes become extremely cold, even to the extent of coating the walls of the crews' spaces with ice from the freezing of the condensed vapour. Such extremes of heat and cold are not experienced on wooden vessels, those latter being cooler in hot climates and warmer in cold.

(2) Steam vessels, from the large amount of coal consumed, attain a much higher temperature than wooden ships. This extra heat is, of course, greater in the neighbourhood of the fur naces. The heat is most excessive in the engine-rooms anc stokeholds. Temperatures of $181^{\circ}$ to $198^{\circ} \mathrm{F}$. have been registered in stokeholds. Firemen's quarters, when they open into the engine-room, are very unhealthy from high temperature, and the evil effect on stokers from working under continued heat and living in such surroundings accounts for the large percentage 
Fras

of who die of heat trouble, affections of the respiratory and nervous systems, and frequently sulcide by jumping overboard from the same cause.

(3) Cargoes also raise the temperature of a ship. Iime, coal, grein, sugar, etc., are apt to undergo chemical changes attended with the evolution of much heat. Cases of spontaneous combustion from cotton waste under pressure have been reported. The obvious remedy for overheating is copiove admission of air by ventilating shafts.

LATRINE ACCOMIODATION.

All sailors' water-closets on board vessels of the mercantile marine are, generally speaking, abominations:-- a small space in which a man cannot stand upright, the seat too high, and furnished with a step such a to render its use velI nigh impositile; others simply a long hopper with a plank across; others trough in shape, filthy and corroded, and the majority of the seats broken. Generally flushed by hand-purp and hose-pipe, or by means of a bucketful of water thrown in by the hand, they are almost invariably very dirty, and frequently choked to the full. The soil-pipes cometimes discharge through the bulwarks, or near the top of the covering board which closes in the upper border of the two "sking" of the ship. In the latter there is risk of leakage into the space between the"skins."

The structure should be sufficient for a man to stand in upright, and should have ample light and ventilation. This latter point ought to be carefully attended to, a port window being supplied, if possible, and the door below furnished with a grating and a few holes near the top. The floor should be of cement, with a good fall outwards. The closet itself should be a galvanized iron hopper, attached to an iron soil-pipe open to the air, the seat to whlch might with advantage be made to Iift 


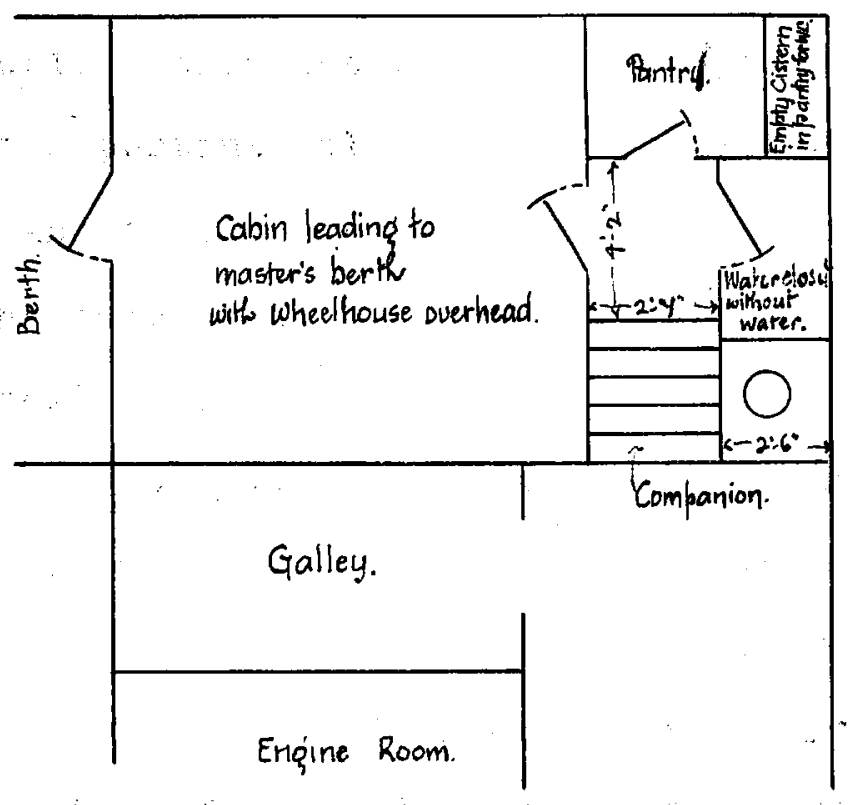

Fig.14. Gegtion through Masters cabin wC. \& Pantry.

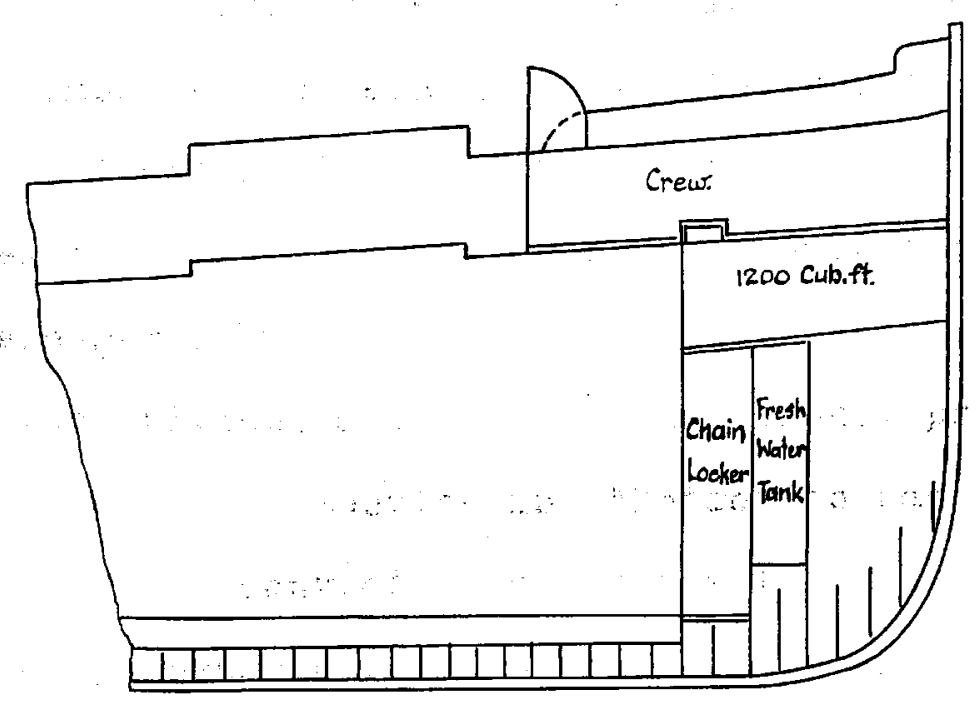

Fig. 15. SEOTION THROUGH Forecastle. 
upon a hinge. The walls of the water-closet also should be regularly limewashed, and kept sweet and clean. Closets should not be close to sleeping quarters, and, if this is not possible, should be divided therefrom either by an efficient iron bulkread or a double wooden one with a layer of felt between. Lastly, and most important, all closets should be flushed from the engine, and those which are flushed only by hand should no longer be tolerated, as they are only open cesspools, and are always neglected.

\section{Figure 14 is an example of a faulty arrangement of} the conveniences on a steamer. The water-closet is at the bottom of the companion, and exactly opposite to the door of the master's cabin. It abuts on the pantry.

The after part of the ship is the best place for the closet, as then the soil-pipe may shoot over the ruddertrunk. When this situation is chosen, a storm-valve may be added to protect the lower end of the soil-pipe, closing against pressure from the outside, to prevent flooding. On some of the smaller schooners there is no latrine accommodation, the men being compelled to defecate over the ship's side. In the Board of Trade's "Instructions as to Survey," section 55, two privies for every 20 of a crew are required on passenger ships. No passenger ship is allowed to clear out unless fitted with at least two privies, and with two additional privies for every 100 passengers. Section 25, "Notice to Passengers," also requires special conventences for female passengers. Foremcabin and deck passengers on home-trade ships are to have closets ir. the ratio of three to every 200 such passengers; and in Section 13, "Board of Trade Instructions as to Survey," It says -"a fair proportion must be allotted to the sole use of women and children." To the Board of Trade surveyor falls the duty of seeing that the various necessary details for the proper arainage and cleansing of merchant ships are carried out; and specific instructions are given him to act upon. Those instructions, 
falling far short of what is required in the interests of health, would receive no approval at the hands of a Medical officer of Health.

\section{IAVATORY ACCOMNODATION.}

It may seem incredible to hear it stated that, in scarcely a vessel in the Mercantile Marine is there such a thing as lavatory accommodation for the aailor. In other words, there is not a wash-hand basin or bath, where he might wash himself and his clothes, and yet in all vessels carrying: Lascar crews a bathroom is provided. This provision for Iascars is simple certainly, in that it is only a square iron compartment which drains out into the scupper; but not even such is provided for the European sailor. Some provision, however simple -. it need not be alaborate -- should be made to enable a man to wash himself. To talk of the want of space for such a purm pose is simply to expose a niggaraly spirit. If the re is room for the cargo, surely there should be at least the barest necessary room for the requirements of the men who work that careo into port. A small space is all that is required, with an enamelled wash-hand basin or two, depending on the number of the crew, and a similarly cheap bath. This could be placed in an iron compartment, like that supplied the Lascars; or, if such could not be obtained, the floor might be cemented or linea with sheet lead and efficiently drained. Nor should there be any difficulty in furnishing a hot supply in any steamer for the water, at any desired temperature, is there, and it only wants a pipe to convey it. It is to be remembered that, after: all, the seaman is a civilised human being, and requires, therefore, at least the barest necessities as such. Too long have his wants been aisregarded, and so utterly disregarded as to furnish the explanation for the gradual diminution in the number of British seamen sailing on British vessels. It does not stimulate the feelings of a loyal British subject to lister to 
the Babel of languages to be heard in many of the forecastlas of our British vessels. The conditions of life at sea are rot such as will attract any others than a class who can do no better, conditions which inevitably lower the tone of any individual vro follows the sea as a profession. If we wish to sustain our maritime supremacy, depend upon it we must do more for the sailor, in order that the race which has made Britain what it is -r the mistress of the seas -- may not be allowed to die out.

Port Local Authorities should combine in one strenuous effort to take over into their own hands the sanitary superviaion of ships, and displace the Board of Trade from a pozition which, up till the present, has been nothing short of a sinecure. The officers of the Board of Trade have no knowledge of the sanitary requirements of a ship, and why not therefore transfer the power to those who are qualified to know. Once Port Joca? Authorities had obtained such power, a vessel, even during and after construction, would then be kept under surveillance in regard to sanitation by competent officers, and the onus of the responsibility in regard to the health of the sailor voulo then rest on the shoulders of the proper party - a party prem pared to do good and to accept such responsibility.

\section{CATTLE SHIPS.}

A large number of such vessels reach this port annually, each carrying, on an average, between 600 and 800 head of cattle, packed away in allerailable corners of the ship -. on the hirricane, upper and main decks. Planks are laid along the decks to permit of a foothold for those animals in rough weather, and during the royage, which may be of fourteen days' duration or longer, their droppings collect beneath them. Great accumulations of manure consequently reach this port, as much sometimes as between 50 and 60 tons of decomposing, fermenting refuse, the juice expressed from which finds its way through crevices to 
all parts of the ship -- invading sleeping quarters, circulating around drinking water tanks, and contaminating bilges.

After a ship has been employed in this trade for some time, it becomes thoroughly saturated with this heavy evil odour, and practically nothing can be done to remove it; and yet those same vessels are permitted alternately to act as passenger and cattle ships. Cattle ships should be built specially for the purpose, and should continue to carry cattle only. The floors of the pens should be properly cemented, with a fall outwaras, and several large port-holes should be provided for dischareine litter by, as well as other structural arrangements to allow of this being done daily whilst live stock are on board. The present system of conveying passengers in vessels soaked throughout with the concentrated essence of animal emanations cancot be too strongly deprecated.

WATER .

Water at all foreign ports is procured from severai sources, such as springs and streams, when having run short on a long voyage. The nature and possible contamination along the course of such streams is disregarded, and has frequently been the cause of producing epidemics of Cholera and Enteric Fever. Frequently ships are supplied from water-boats, from which it is pumped into the ship's tanks. But how Iong such water has remained in those water-boats, how often they are emptied and thoroughly cleansed out, and a fresh supply taken in, are questions which must remain unanswered. On many occasions the water is taken directly from the river, with consequent evil results. When water above suspicion (preferably a tom's supply and well filtered) is not obtainable, then distillation from sea-water, as practised on some of the larger vessels, should be carried out as a safeguard. It is not only necessary that the water-supply be of the purest quality, but it is also 
requisite that its storage on board ship should receive paricular attention. In large vessels the water is stored in galvanised Iron tanks, each with a capacity varying from 300 to 900 tons. Iron tanks have many advantages, and are generally recommended as being the most suitable, economical, and, at the same time, the most sanitary receptacles. Tnose tanks are usually stored in the holds, amidships, aft the engine-room, after part of the vessel in the hold, forward or sometimes in the fore-peak, immediately below the seamen's quarters. This latter situation is undesirable for the above-stated reason, as also on account of its proximity to the chain locker, water-closets, paint and lamp lockers.

Figure 15 represents a section through the forecastle of a vessel in which the fresh water tank adjoins the chain locker, immediately below the crew's quarters.

Tanks are sometimes placed under cabins below deck, and sometimes under lower forecastles -- situations open to many objections, the principal one being the pollution of water by dirt finding its way, through defective floors and ill-fitting hatches, on to the top of the tank or the interior through the dripping hole.

The most common situation for drinking water tanks is in the lower holds, abutting on the engine-room bulkhead. The only objection to this arrangement exists in its close proximity to the engines, where the water is usually raised in temperature. In such cases a gravitation tank on the lower bridge, fed from the lower ones by means of a steam pump, would meet the difficulty, and furnish water in a measure cooled and aerated.

The chief objection to tanks is their inaccessibility for cleansing and repairs. They should be furnished with large manholes for the purpose of cleansing, which should be carried out as a matter of routine after every voyage. 
If possible, the manhole should be placed in such a position that natural light finds its way into every part of the tank when the cover is removed. They should be regularly cleansed, cement-washed, and then limewashed; and water ballast tanis used for storage of drinking water, being dangerous to health, should be discontinued.

Under the Passengers' Acts, it is provided that the supply of fresh water to passenger ships shall be sufficient. to secure throughout the voyage three quarts daily to each statute adult (exclusive of the amount necessary for cooking), and that the latter shall be shipped "after the rate of at least 10 gallons for every day of the prescribed length of the voyage for every one hundred statute adults on board, and also for the $u$ se of the crew and all other persons on board an ample supply," etc.

$F O O D$

The true economy and importance of providing the sailor with plenty of good food should be self-evident, and its adrocacy unnecessary. Yet sufficient attention to this matter has not been given, and even the diet to-day falls far short, in many instances, of what is required for the sustenance of health. Not only is the bare amount required not supplied, but no consideration is given to varying circumstances of ship-life in port and at sea, in temperate and tropical climates. There is not sufficient variety, and even now, in spite of the great improvements in packine and preserving fresh meat, too great reliance is put upon salt meat. It has been stated by many observers that the too frequent use of salt meat is a cause of digestive ailments, and by others that brine alters the composition of flesh, separating the albumen. If long kept, it becomes hard and indigestible. Salt proviaions and dry vegetables as a continued diet are important factors in the causation of scurvy and Beri-Beri. 
also Irequently undergo fermentative changes, producing Ptomainepoisoning, etc., when consumed.

The quantity of fresh vegetables might be consideratily increased. There is no difficulty in drawing up a far more liberal and varied diet scale without in any way increasing the cost to the owner, and it is scarcely necessary to point out how largely the nature of the food supplied affects, not only the health but the temper of the men. Moreover, there is good reason to believe that the compulsory issue of limejuice has not been an unmixed benefit. It undoubtedly is a powerful anti-scorbutic, and is valuable ad hoc, but, at the same time, with some there has been a feeling that, by this law, the Government has accepted a certain amount of responsibility, and so far relieved the owners from the necessity of raising the diet scale.

All food-stuffs supplied to ships should be carefully examined as to quality. The Merchant Shipping Act of 1892 provides that, in the case of ships trading, or going from any port of the United Kingdom through the Suez Canal, or round the Cape of Good Hope or Cape Horn, an officer of the Board of Trade shall, before shipment, whenever practicable, inspect the barrels of beef and pork, preserved meat, and vegetables in tins, and the casks of flour and biscuits intended for the use of the crews of such ships, and, if satisfied they are fit for such use, certify the same accordingly. He may also proceed on board the vessel to ascertain whether the stores and water provided have been duly inspected, or, if not, whether they are of a quality fit for the use of the crevs of such ship. If he finds the same not to have been inspected, and deficient in quality, he is required to detain the ship until such defects are remedied to his satisfaction. Rulesfor the inspection of provisions and water under this Act of the Board of Trade, March 1893, define the conditions of inspection. and provide for the inspection of burplus stores let't over from 
a previous voyage, and for exposing the contents of all casks of wet provisions anong such surplus stores. Other provisions of these Rules relate to notice being given to the inspector for the inspection of stores, and for furnishing him with a list of the stores. The condition of pork, beef, preserved vegetables and meats, and vegetables in tins, biscuits, and flour required by them is stated. In short, animal food is to be sweet and properly packed, and pickled in pickle of full strength; vegetables to be fresh and sound, properly preserved, and in strong and suitable tins. Flour must be of fine quality, milled from fully matured good souna wheat containing a proper proportion of nutritious matter. When stored in tanks, they are to be thoroughly cleansed, lined with fresh lime and aried before being refilled.

Any water remaining in the ship's tanks from a previous voyage must all be completely emptied, and the tanks thoroughly cleansed and re-filled with good fresh vater. The inspector is empowered to require that all stores deficient in quality shall be landed, and it is hic duty to grant a certificate if he is satisfied that he has seen all the stores intended for the particular voyage, and that they are of a quality fit for consumption by the crew.

Another Rule proviaes for the exemption from inspection of the stores of a ship trading only in parts of the United Kingdom, and which have not been broached. It will be seen, therefore, from the above, that the Board of Trade are not wanting in rules and regulations, but, as for rigorously carrying them out, that is a different matter.

\section{COOKING .}

While, however, an improved dietary need not increase the cost, there is another very important point, which, if properly dealt with, can only lead to increased economy and actual saving - ․‥e., cooking. 
of late years a considerable amount of attention has been called to the absolute necessity of some proper system of training and certifying cooks on board ship. It is scarcely possible to exaggerate the importance of this responsible personage, holding as he does completely under his sway the otomachs and digestion of all on board. Notwithstanding this responsibility, there is no provision for his training, and, as a general rule, he grows up into the position -- learns $h$ is art, if it can be so called, by tradition from others possibly more ignorant than himself. The Royal Commission on Labour of 1894 said:-- "We regard it as important to the seamen's health that some qualification, however elementary, should be required before a man is engaged as cook."

There is no reason why a school of ship's cookery should not be established at every large port, and a regular course of instruction given to those who are desirous of obtaining billets; after a certain time it might be found advisable to insist that every cook on board a vessel beyond a certain size should be required to attend such a school and obtain a certificate of proficiency. In the meantime much can be done by such institutions as training ships, etc., which have already moved in this direction; obviously such a regulation would lead to some slight additional cost, but this would be far more than balanced by the economy of food and the improved dietary it would undoubtedly bring about.

PRESERVATION OF FOOD.

The following are some of the processes for preserving food of different kinds:--

Desiccation;

Salting;

Smoking;

Immersion in Vinegar (animal and vegetable foods);

Immersion in $0 i 1 . . . . . . \ldots . .$. (fish, etc $)$;

Immersion in Molasses...........potatoes);

Refrigeration;

Heating; and

seclusion from atmosphere (as in tinned foods, soups, fruits, etc.). 
Drying is not in general use in this country.

Salting reduces the nutritive value.

Desiccation by pressure for vegetables is practised, when they are said to regain their former freshness after immersion in warm water for about 30 minutes.

Probably the best method of preserving meat is that of plunging tins of meat into water at a temperature of about $260^{\circ} \mathrm{F}$. This temperature is obtained by dissolving certain salts In the water to raise the boiling point. The steam created by this high temperature then drives out the air, when the tins are closed and soldered.

PROVISIONS.

Boyd's Merchant Shipping Jaws, 1876, states--

"Any three or more of the crew of a British ship may complain to any officer in command of Her Majesty's ship or any British Consular Officer, etc., that the provisions or water for the use of the crew are bad; the person who receives such complaint, after inspecting the food and finding it defective, may inform the master of the ship, who shall be liable to a penalty of twenty pounds in case of failure to provide proper provisions, etc., in lieu thereof."

The average food allowance in foreign-going British

Merchant Ships is:--

$1 \frac{1}{2}$ Ibs. of beef, or $1 \frac{1}{4} 1 \mathrm{bs}$, of pork, on alternate days.

$\frac{1}{2}$ 1b. of flour, or $\frac{1}{4} 10$. of peas, on alternate days.

I 1b. of bread every day.

The defects of such a diet may be stated briefly under

three heading :--

(1) They are too unvarying in all latitudes, tropical or temperate.

(2) The same diet is given in warm and cold regions, instead of one less nitrogenous and stimulating, especially in the tropics.

(3) The small supply of vegetable matter and very salt pork and beef are injurious, especially in the tropics. 
SCALE OF DIETARY FOR PASSEMGERS.

(Board of Trade Notice to Passengers, 1887.)

-...........................

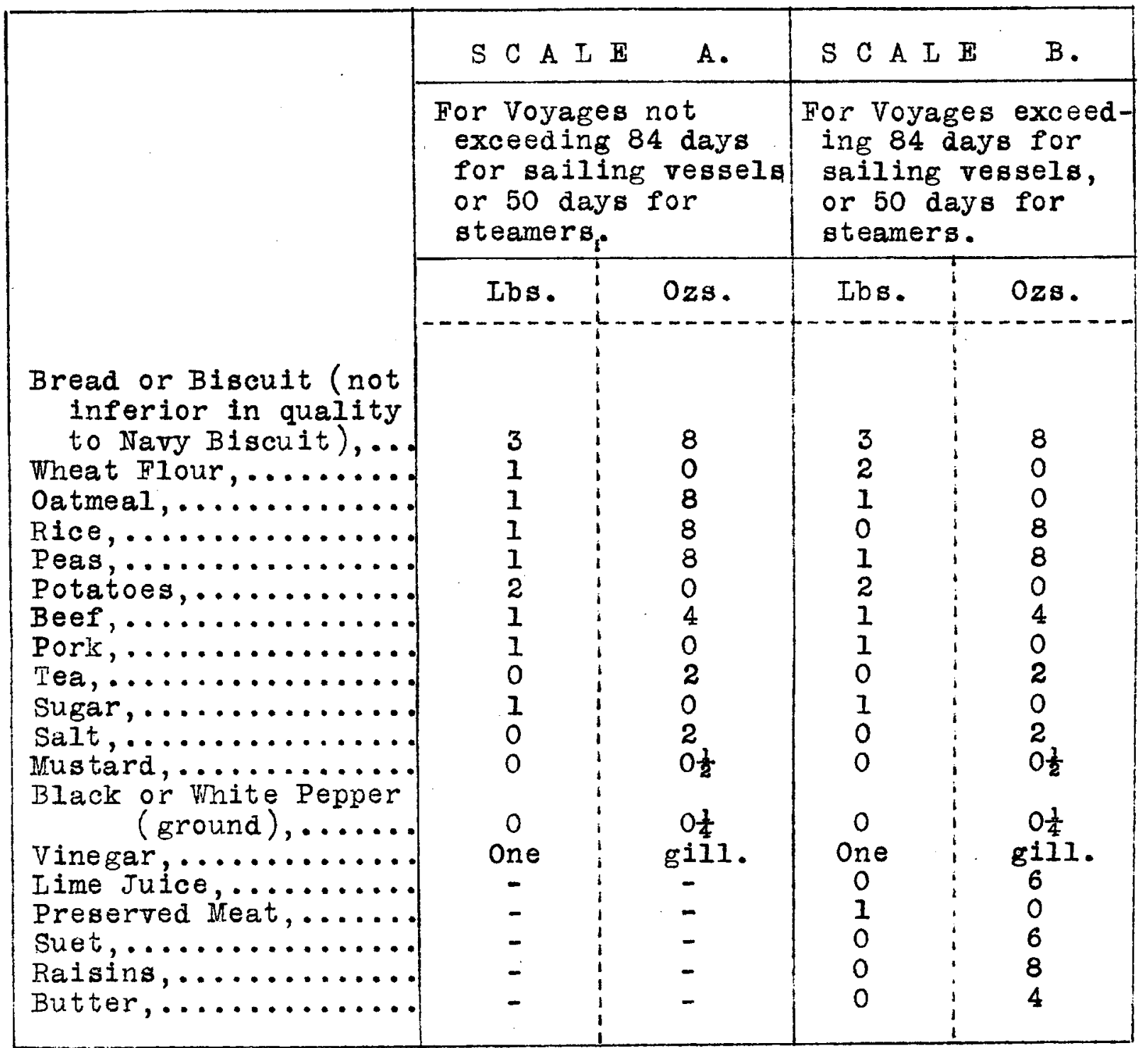

SUBSTITUTIONS.

1 15. preserved meat............for 1 1b. salt pork or beef.

1 1b. flour or bread or biscuits

th. beef or pork $\ldots \ldots \ldots \ldots \ldots \ldots \ldots\}$

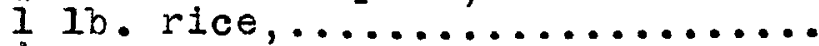

$\frac{1}{4} 1 b$. preserved potatoes, ...........

10 ozs. currants,..............

$3 \frac{1}{2}$ ozs. cocoa or coffee roasted

or ground,.............

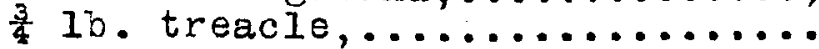

1 $1 \frac{1}{2} 1 \mathrm{bs}$. Oatmeal or

1 gill mixed pickles,..........

" 1 1b. rice or $11 \mathrm{~b}$. peas.

" $1 \frac{1}{2} 1 \mathrm{~b}$. oatmeal or vice versâ

$" 1$ lb. potatoes.

" 8 ozs. raisins.

" 2 ozs. tea.

" $\frac{3}{2}$ 1b. sugar.

" I gill vinegar.

The master is liable to a penalty not exceeding Fifty Pounds in case of failure to supply issues of good and wholesome provisions, in accordance with above scale. 
CLOTHING.

There are no regulations in the British Mercantile Marine as to the outfit of seamen. Each man provides for himself as he thinks fit, and the result is want of uniformity. The United States' Mercantile Marine affords us a good lesson in this respect, for it is directea by Statute "that every vessel is to be provided with at least one suit of woollen clothlng for each seaman." The hygienic advantage of warm underclothing for seamen need not be enlarged on. It is somewhat surprising that the Cholera Belt, a girdle of flannel, three to four feet long and four inches wide, is not more universally worn in warm climates as a preventative against chills and ảysentery.

CARGOES.

Cargoes play an important part in the sanitary condition of a vessel. They may be dangerous to life and health from the following causes:--

(1) Infection.

(2) Decomposition and evolution of noxious gases.

(3) Combustion.

(4) Shifting.

(1) Infection:- One of the most dangerous cargoes on account of infection is that of rags, of which a large quantity reach Glasgow yearly from foreign. It is recorded that Small-pox and Cholera have been communicated by this means. The following table shows the total amount of such goods arriving in Glasgow from foreign and coastwise during the year, comprising articles which experience has shown are either likely to be diseased or to convey disease to this country. 


\begin{tabular}{|c|c|c|c|c|}
\hline $\begin{array}{l}\text { With special re- } \\
\text { ference to the } \\
\text { introduction of }\end{array}$ & Articles. & $\begin{array}{l}\text { Fr } \\
\text { For }\end{array}$ & $\frac{n}{i_{g n}}$. & Coastrise. \\
\hline PIAGUE, & 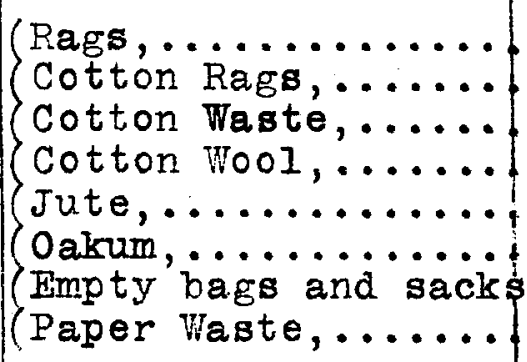 & $\begin{array}{r}110 \\
35 \\
6 \\
9 \\
667 \\
10 \\
53 \\
80\end{array}$ & $\begin{array}{l}\operatorname{tons} . \\
\text { do. } \\
\text { do. } \\
\text { do: } \\
\text { do. } \\
\text { do. } \\
\text { do. } \\
\text { do. }\end{array}$ & $\begin{array}{l}2,142 \text { tons. } \\
1,027 \text { tons. } \\
5,462 \text { do. } \\
474 \text { do. } \\
14 \text { do. } \\
767 \text { do. } \\
733 \text { do. }\end{array}$ \\
\hline ANTHRAX, & 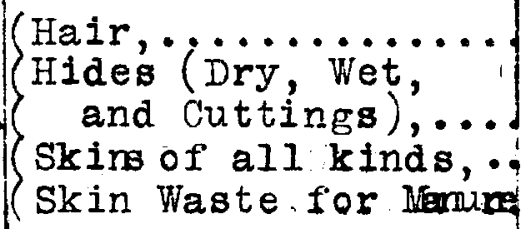 & $\begin{array}{r}2,259 \\
448 \\
307 \\
\quad . \quad\end{array}$ & $\begin{array}{l}\text { tons. } \\
\text { do. } \\
\text { do. }\end{array}$ & $\begin{aligned} 87 & \text { tons. } \\
1,428 & \text { do. } \\
395 & \text { do. } \\
46 & \text { do. }\end{aligned}$ \\
\hline FINTERIC HEVER, & $\left\{\begin{array}{l}\text { Mussels }, \ldots \ldots \ldots \ldots \\
\text { Shell-fish, } \ldots \ldots \ldots\end{array}\right.$ & $\because \dot{*}$ & $\ddot{0}$ & $\begin{aligned} 882 & \text { tons. } \\
62 & \text { do. } \\
420 & \text { do. }\end{aligned}$ \\
\hline
\end{tabular}

(2) Foul Cargoes:-- Bones, potatoes, fish, frult, onions, guano, manure, etc., are apt to be a nuisance or injurious to health.

(3) Cargoes liable to undergo spontaneous combustion, thus endangering the lives of those on board:- ccal, cotton, hemp, rags, grain, sugar, lime, and soda.

\section{(4) Shifting:-- Sect. 22 of 39 and 40 Vict., c. 80 ,} provides that -- "No cargo of which more than one-third consists of any kind of grain, corn, rice, paddy, pulse, seeds, nuts or nut kernils, shall be carried on any British ship unless contained in bags, sacks, or barrels, or secured from shifting by boards, bulkheads, or otherwise.

FOOD INSPECTION.

Frozen meat from Australia is brought here in large quantity, and occasionally goes wrong during the voyage from accidental or other causes. Dr. Williams, the Nedical Officer of Health of the Port of London, has done much valuable work in 
the detection of such, and, as a result, has condemned many thousands of tons of meat which would otherwise have found its way into the various London markets, much of which would probably have escaped the vigilance of the authorities and been consumed by the public. Dr. Williams deserves all credit for this departure, and other Port Local Authorities should adopt similar measures. He reports that during the year 1902 three large quantities had to be dealt with, viz.:--

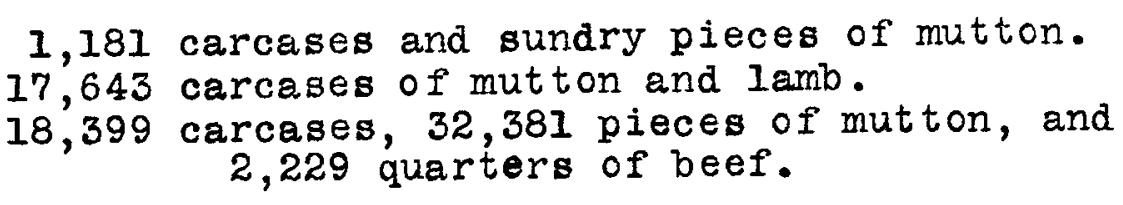

The following is a summary of the articles seized and destroyed during the year 1902, from which it will be seen that the quantities are not only large but of a most varying description:--

\begin{tabular}{|c|c|c|c|}
\hline Description. & $\begin{array}{c}\text { Number of } \\
\text { original packages }\end{array}$ & $\begin{array}{r}\text { Sundry } \\
\text { oddments } \\
\text { etc. }\end{array}$ & $\begin{array}{l}\text { Sundry } \\
\text { Quantities } \\
\text { by weight. }\end{array}$ \\
\hline 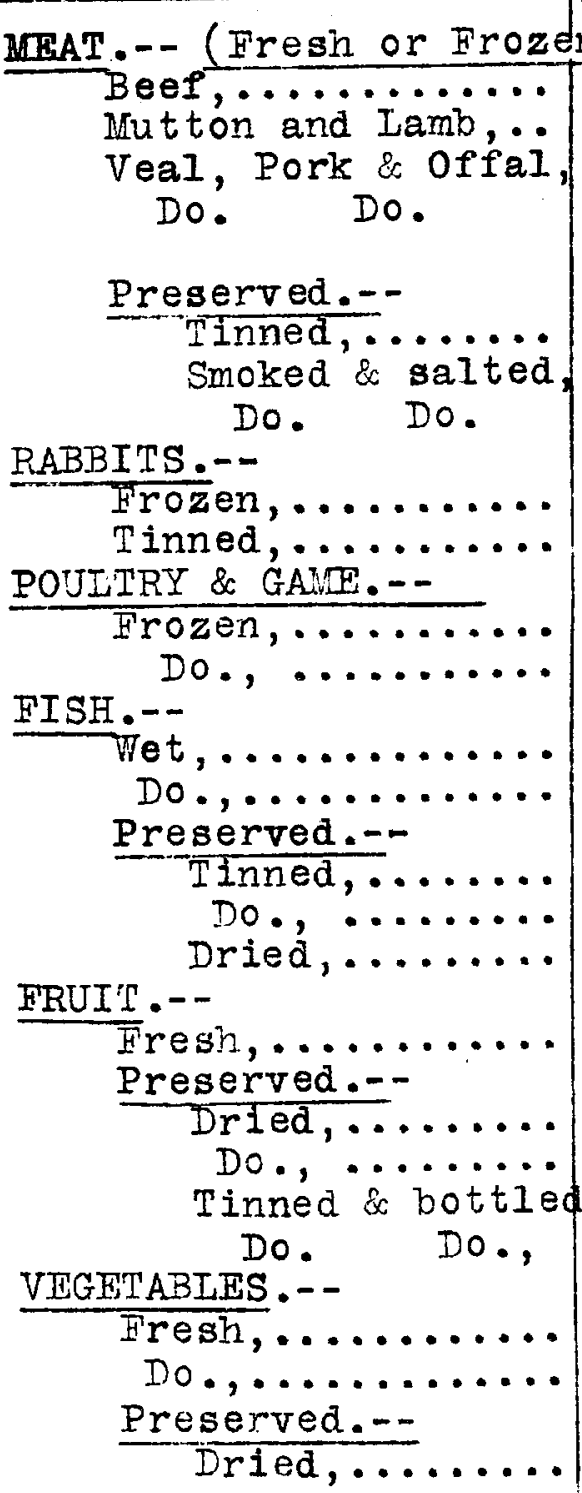 & $\begin{array}{l}\text { n) } 2,292 \text { quarters. } \\
38,373 \text { carcases. } \\
110 \text { cases. } \\
\text { 369 cases. } \\
41 \text { packages. } \\
- \\
27 \text { crates. } \\
2,987 \text { tins. } \\
3 \text { packages. } \\
-\quad \\
2 \text { packages. } \\
-\quad \\
124 \text { cases. } \\
2,339 \text { tins. } \\
3 \text { packages. } \\
3,641 \text { packages. } \\
2,340 \text { packages. } \\
- \\
1,215 \text { cases. } \\
- \\
1,312 \text { bags. } \\
- \\
128 \text { bales. }\end{array}$ & $\begin{array}{c}108 \\
33,368 \\
- \\
- \\
516 \text { ting } \\
34 \text { pieces } \\
- \\
- \\
- \\
310100 \text { s\$ } \\
- \\
- \\
- \\
- \\
-\end{array}$ & $\begin{array}{c}- \\
3 \text { tons. } \\
- \\
3 \text { cwts. } \\
4 \text { cwts. } \\
5 \text { cwts. } \\
-\end{array}$ \\
\hline
\end{tabular}


(Continuea)

\begin{tabular}{|c|c|c|c|}
\hline Description. & $\begin{array}{l}\text { Number of } \\
\text { original packages. }\end{array}$ & $\begin{array}{c}\text { Sundry } \\
\text { Oddment s, } \\
\text { etc. }\end{array}$ & $\begin{array}{l}\text { Sundry } \\
\text { Quantities } \\
\text { by weight }\end{array}$ \\
\hline 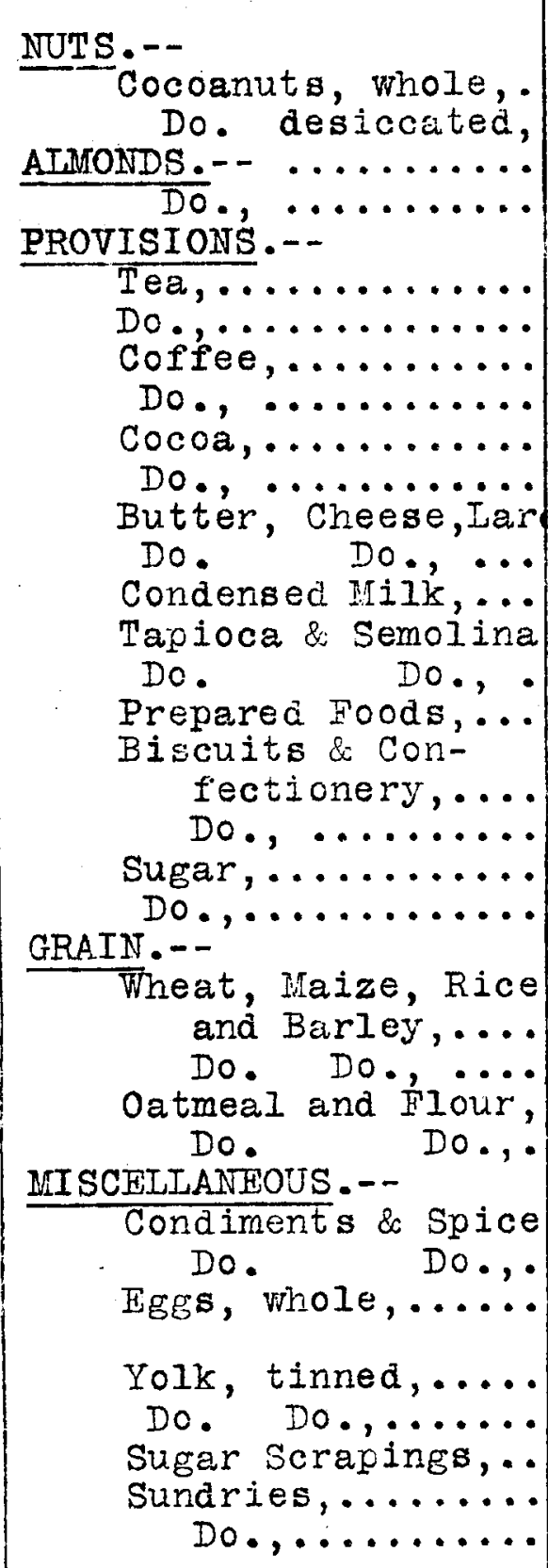 & \begin{tabular}{|c}
5,390 \\
-5 boxes. \\
- \\
830 chests. \\
-504 packages. \\
-638 packages. \\
$-\overline{337}$ packages. \\
2,003 cases. \\
41 packages. \\
$-\overline{587}$ packages. \\
518 pacirages. \\
-2 packages.
\end{tabular} & $\begin{array}{c}- \\
- \\
- \\
- \\
= \\
2,000 \\
100 \text { se. } \\
- \\
= \\
= \\
-\end{array}$ & 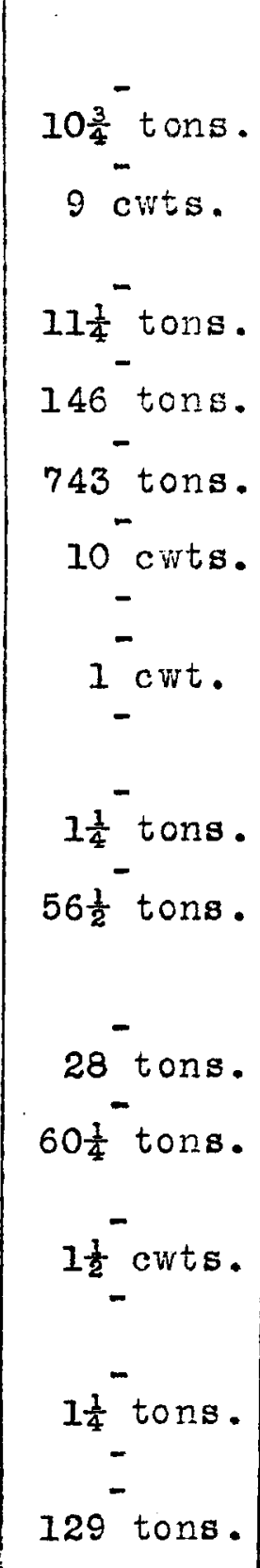 \\
\hline
\end{tabular}

Some casks which, according to the manifest, contained "grease", were found packed with Iivers, kidneys, and hearts in a putrid condition, intended for the preparation of "table delicacies." Other casks enpposed to contain "meat" were found to contain flesh chopped up into small pieces of about one inch cube, putrid and intended for manufacture into sausages, the nature of the "meat" in question being extremely doubtrul. 
The most frequently occurring febrile disorder amongst Merchant Seamen is Interic Fever; then come. Small-pox, "Continued Fever," Scarlet Fever, Erysipelas, Measles, and Diphtheria. Bolls and obstinate constipation are also very common. But the most prevalent diseases are Rheumatism, Catarrhs, Pleurisy, and Pneumonia.

CHOLER A............ This is a disease which is more frequently met with in tropical reglons, such as India and China. Occasionally, however, it assumes an alarming increase, and spreads rapidy alone definite lines of traffic, even reaching our own shores on several occasions. During 1902 this disease was in virulent and epidemic form in many localities -. in India, China and Japan, Arabia, Egypt, and other countries. It extended from China to the Philippine Islands, and also from Egypt to Palestine. The Egyptian outbreak seems to have originated from Mecca in Arabia, and may almost certainly be ascribed to pilgrims from India, the home of Cholera. Those pilgrims carried it to Egypt, where Cholera broke out on a considerable scale. The village first attacked was Moncha in the Delta -- here the wells became infected, and the disease spread repidiy. Several days afterwards it broke out in Cairo, in a refugee from Moncha; next day there were 30 , and on the following day 100 deaths all over. It even spread to Alexandria, Port Said, Suez, Gaza, and Jaffa. As the winter approached, the epidemic greatly declined, and last year Egypt was free from the disease. Recent information points to the fact that an outbreak of Cholera has occurred in St. Petersburg, and that precautions have been adopted in order to effectively deal with it. -All mesters of vessels should avoid, if possible, obtaining water and fresh vegetables in countries where Cholera occurs. YEILOW EEVER.. The old haunts of this disease are the coasts of Solith America, the River Amazon, and the Gulf of Mexico, where it still lingers. The disease has been eradi- 
cated at Cuba. The following ports arestill affected:-Manaos, Rio de Janeiro, Para, Panama, and the chief ports of the Gulf of Mexico.

PIA G U E:-...-.- is closely connected with ships, and the contagion of it has been brought by them to this country. Glasgow was infected with Plague during the years 1901-02, but, as a result of the precautionary measures adopted by the Health Authorities there, a recrudescence of the disease was prevented. In Egypt, the cities of Alexandria and Assiout, and the provinces were infected up till last year. It also reached Odessa, Constantinople, and smyma. It is, however, in Incia, and the farthest East, that the disease is working greatest havoc, where just now tens of thousands are dying weekly. China is still infected; Formosa and Yoirohama have had cases up till quite recently. From Yokohama it was conveyed to Tokio, and, according to official reports, was brought to thet city in cotton imported through a Japanese firm doing business in Yokohama. In South Africa, Cape Colony has had some cases during the year, and two cases with one death are to-day recorded at Port-Elizabeth. Plague-infected rats continue to be found in that town and East London. Mauritius has had a bad record, also, for the year, and again this fortnight 50 cases are reported, with 32 deaths. A heavy nortality was noticed amongst rats in the infected districts during the time of the last outbreak of Plague at Durban.

\section{United States:-- Considerable danger to the United}

States lay in the existence of a definite nidus of plague at San Francisco, which was for a long time ignored by the official state Board of California. This danger existed during nearly three years in that part of San Francisco known as "China Town." At a special conference of the United States' Boards of Health a resolution was passed, emphasising the fact that the gravity of the circumstance was greatly increased by the gross neglect of official duty of the State Board of Health of California. 
Mexican Coast.-- Plague appeared at Mazatalan on the Mexican coast. From here it was carried to Ensanada, which is close to the United States' frontier. Chinese direct from China are presumed to have brought the disease direct or after transhipment at San Francisco to Mazatalan, afterwards making their way to Ensanada. No extension eastwards across the States occurred, and the North Atlantic seaboard remained free from Plague.

EINTERIC FEVER:- Masters of vessels should avoid water of a suspicious nature whilst in foreign ports, especially along the South American seaboard, and adopt as a safeguard either boiling all the water obtained from those rivers or use distilled water.

BERI-BERI \& DYSENTERY:-- are reported to have occurred amongst the troops now engaged in the Far East.

In the statistics of medical cases admitted into the Seamen's Hospital, London, in the decade, 1880-89, Drs. Curnow and Smith state that:-- "Sailors suffer in greater proportion than residents in this country from such diseases as -- Enteric Fever, Malaria, Aneurisms, Dysentery, and Abscess of the Liver." The authors specially call attention to the large number of cases of Phthisis (nearly one-seventh of the total), and believe that, with better food and improved ventilation of the sleeping rooms, this could be decreased. Chronic rheumatism, as might have been anticipated from the constant exposure to wet and cold and from a poor diet, "figures very largely." Pneumonia is"always very severe." "Enteric Fever is still very common, and, like Dysentery, is due to the water-supply being infected." Cases of Scurvy have reduced in number from 101 in 1865 to 2 in 1902, the reason attributed being the increase in steam-shipping and decline in the number of sailing vessels in recent years. Shorter voyages mean fresh supplies of food, and this must eventually lesd to a practical extinction of the disease. 
The Registrar-General of Shipping and Seamen calculated that the rate of suicide amongst firemen and trimmers in the Mercantile Marine was about 1 in 900, as against 1 in 5,000, taking ages between 20 and 55 furnished by the Registrar-General of Births and Deaths on shore. "There can be little doubt, concludes the Registrar, that the figures as regards suicide or supposed suicide fairly represent the actual condition of trings, and though the rates of suicide I have given, based as they are on estimates, may be criticised, no amount of criticism will obscure the fact that suicide amongst firemen in our Mercantile Marine Bervice is prevalent to a degree calling for serious attention."

CONCLUSION.

It is surprising how few people there are, except those immediately concerned, who have any practical knowledge of the amount of sanitation or otherwise which obtains in the ships of the Mercantile Marine. It is a subject that deserves attention, as it affects a class of men whose hardships and privations we daily read about, and the death-rate amongst whom compares very unfavourably with that of other dangerous callings. Crew's quarters can, and ought to be in such a position on a vessel as to render them habitable under ordinary conditions; and, until thet is aone, the main object, from a hyeienic point of view, is not attained. With vessels built of all shapes supervision when in the hands of the builders is absolutely indispensable. The structural alterations ordered by Port Local Authorities, after the vessel leaves the builders, are frequently indirectly the fault of the administration. Again, and this is a point which is frequently overlooked, it costs no more in the first place to provide accommodation for crews in accordance with sanitary laws than to follow a contrary course. 
Perfection should always be the direction aimed at by human efforts, however imperfect may be the result; and the success of sanitary legislation will be measured by the nearness or the distance of its actual results from the perfect idea. This is the spirit in which the Public Healtr Acts of this country have been enacted from time to time for the good of the people and the country generally. To Sanitary Scientists much is due for their untiring energy in this direction, but, however much they have advanced the science of how to live healthily, their efforts in the main have been devoted to the laws which govern the elements on shore; and, although the same natural laws apply to vessels afloat, still the construction of a ship differs so much from that of a house that, to obtain a like degree of success, a greater attention to the subject is needed. 